\title{
Mind the Gap: How Do Credit Market Experiences and Borrowing Patterns Differ for Minority-Owned Firms?
}

Alicia Robb, Mels de Zeeuw

Community and Economic Development Department

Federal Reserve Bank of Atlanta
Brett Barkley

Federal Reserve Bank of Cleveland

\section{Primary issue:}

Given the relationship between a small business's access to financing and its outcomes, and given the growing share of minorities in the U.S. population, it is important that creditworthy firms and entrepreneurs, irrespective of race or ethnicity, are able to secure adequate financing to achieve growth and success. Data from the Federal Reserve System's 2016 Small Business Credit Survey allow for a closer examination of the experiences of minority-owned small businesses in applying for and obtaining financing.

\section{Key findings:}

The authors find evidence for disparities in credit approval by the race or ethnicity of the business owner. Notably, black-owned firms are less likely to receive approval for financing when compared with otherwise similar whiteowned firms. Additionally, black-owned firms feel discouraged from applying for financing at significantly higher rates. Also, Hispanic- and black-owned firms are more likely than white-owned firms to apply for financing at nonbank online lenders, though both groups do not appear to have a significantly different chance of being approved. Finally, the authors find minority-owned firms are more likely to be dissatisfied with their lender.

\section{Takeaways for practice:}

Greater knowledge of minority-owned firms' financing needs and disparities is crucial to understand and bolster the small business sector, an important component of the U.S. economy. The findings can inform policymakers and workforce and economic development practitioners who aim to boost small business formation and improve the broader economic well-being of minorities in the United States. Potential approaches to address some of the differences between white- and minority-owned businesses could include technical assistance, such as training in business management practices, or financial literacy programs aimed specifically at minority business owners. Programs that address language barriers for immigrant-owned businesses could also have an impact.

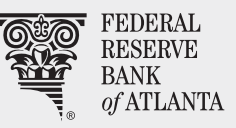

Follow Atlanta Fed CED on $y$

\section{The Federal Reserve Bank of Atlanta's Community \& Economic Development (CED) Discussion Paper Series} addresses emerging and critical issues in community development. Our goal is to provide information on topics that will be useful to the many actors involved in community development-governments, nonprofits, financial institutions, and beneficiaries. Find more research, use data tools, and sign up for email updates at frbatlanta.org/commdev. 


\section{Mind the Gap: How Do Credit Market Experiences and Borrowing Patterns Differ for Minority-Owned Firms?}

\section{Abstract:}

Given the relationship between a small business's access to financing and its outcomes, and given the growing share of minorities in the U.S. population, it is important that creditworthy firms and entrepreneurs, irrespective of race or ethnicity, are able to secure adequate financial resources to achieve growth and success. This paper employs data from the Federal Reserve System's 2016 Small Business Credit Survey to explore under what conditions credit market experiences differ for various racial and ethnic ownership groups of small employer firms.

The authors find evidence of disparities in credit approval by the race or ethnicity of the business owner. Notably, black-owned firms are less likely to receive approval for financing. Additionally, black-owned firms report being discouraged from applying for financing at significantly higher rates when compared with otherwise similar white-owned firms. Hispanic- and black-owned firms are more likely than white-owned firms to apply for financing at nonbank online lenders, though both groups do not appear to have a significantly different chance of being approved compared with white-owned firms. Finally, the authors find minority-owned firms are more likely to state they are dissatisfied with their lender.

JEL classification: D22, G21, G23, J15

Key words: small business finance, minority-owned businesses, Small Business Credit Survey, small business, entrepreneurship

\section{https://doi.org/10.29338/dp2018-03}

\section{About the Authors:}

Alicia Robb is the founder and CEO of Next Wave Impact, an early-stage venture capital firm. She is also a visiting scholar with the University of Colorado-Boulder and the Federal Reserve Bank of Atlanta. She was previously a senior fellow with the Kauffman Foundation for more than a decade and currently does economic consulting for a variety of public and private entities. She is also the founder and past executive director and board chair of the Foundation for Sustainable Development, an international development organization working in Latin America, Africa, and India. Robb received her master of 
science and PhD in economics from the University of North Carolina at Chapel Hill. She has previously worked with the Office of Economic Research in the Small Business Administration and the Federal Reserve Board of Governors. In addition to numerous journal articles and book chapters, she is the coauthor of Race and Entrepreneurial Success, A Rising Tide: Financing Strategies for Women-Owned Businesses, and The Next Wave: Financing Women's Growth Oriented Firms. Some of the boards and advisory boards she serves on include the Deming Center Venture Fund and the Good Food Institute.

Brett Barkley is a data scientist in the Supervision and Regulation Department at the Federal Reserve Bank of Cleveland. Barkley joined the Cleveland Fed in 2014 as a graduate intern and assumed his current position in November 2017. Prior to joining the bank, Barkley received a graduate fellowship from the U.S. Department of Education to study the economic and environmental impacts of refugee settlement in host communities, for which he conducted research in Jordan and Turkey. During his studies, he also worked for the Chicago Metropolitan Agency for Planning and the World Resources Institute. Previously, he served with a nonprofit in Kenya assisting with its microfinance operations and teaching workshops in microenterprise. Barkley holds a master's degree in urban planning and a master's degree in applied economics, both from the University of Illinois at Urbana-Champaign, and a bachelor's degree in economics from George Mason University. He is a member of the Urban Land Institute and the Association of Public Policy Analysis and Management.

Mels de Zeeuw is a senior research analyst for the Federal Reserve Bank of Atlanta's Community and Economic Development (CED) group. Prior to joining the Atlanta Fed, de Zeeuw was a research associate at the Andrew Young School of Policy Studies' Center for State and Local Finance and Fiscal Research Center, where he coauthored various briefs and reports on state and local fiscal policy in Georgia as well as a report on Connecticut's revenue structure. He holds a bachelor of arts in political science and a master of arts in American history from Leiden University in the Netherlands. De Zeeuw earned a master's degree in economics from Georgia State University.

Acknowledgments: The authors would like to thank Ann Carpenter, Karen Leone de Nie, John Robertson, Mark Schweitzer, Ellie Terry, and Keith Wardrip for their diligent feedback and suggestions. Any remaining errors are the sole responsibility of the authors. The views and conclusions expressed herein are those of the authors, and not necessarily those of the Federal Reserve Bank of Atlanta or the Federal Reserve System.

Comments to the authors are welcome at Alicia.robb@colorado.edu, Brett.Barkley@clev.frb.org, and Mels.deZeeuw@atl.frb.org. 


\section{Introduction}

Access to financial capital for small businesses is a major issue confronting policymakers in the United States. Given the important role young firms and small businesses more generally play in job creation, ${ }^{1}$ and given the relationship between access to capital and successful small business outcomes (Fairlie and Robb, 2008), it is paramount that creditworthy firms and entrepreneurs, irrespective of race or ethnicity, are able to secure adequate financing to achieve growth and success. This is especially important since minorities ${ }^{2}$ make up a substantial and fast-growing share of the U.S. population. In 2017, minorities comprised 39 percent of the U.S. population, up from 33.9 percent in $2007 .{ }^{3}$ However, business ownership rates among minorities lag those of non-Hispanic whites. In 2015, minority business owners owned 19 percent of small businesses with less than 500 employees that are classifiable by race or ethnicity, which is up from about 13 percent of similar sized firms in $2012 .{ }^{4}$ Ensuring that minorityowned firms have adequate access to financial capital is thus vital in order for small businesses to drive innovation, growth, and job creation in the U.S. economy.

Given the above, and using recent data from the Federal Reserve System's 2016 Small Business Credit Survey (SBCS), we aim to explore under what conditions credit market experiences differ for various racial and ethnic ownership groups of small employer firms, ${ }^{5}$ including non-Hispanic white-, nonHispanic black-, Hispanic-, and Asian-owned small businesses.

Among these experiences, we will examine loan or line of credit application rates, a firm's likelihood to shy away from applying, overall approval rates, application and approval rates for online lenders, and lender satisfaction rates.

We have organized the discussion paper as follows. The next section provides a literature review of previous research on the topics of racial and ethnic differences in business financing and credit market experiences. Next, we describe the SBCS data used in this paper, and how they compare with other data sets on small business and entrepreneurship. We then provide more detail on the 2016 SBCS, as well as some descriptive statistics, which compare minority- with nonminority-owned businesses along a number of dimensions. We follow with a more in-depth examination of the credit market experiences of black- and Hispanic-owned businesses; we break out businesses by a number of factors such as firm age, firm size, and firm credit risk; and we employ multivariate regressions to examine credit application and credit outcome variation among various types of firms. We conclude the paper by offering avenues for further research and some considerations for public policy.

\footnotetext{
${ }^{1}$ U.S. Bureau of Labor Statistics' Business Employment Dynamics data show firms with between 1 and 499 employees added about 1.4 million net new jobs in 2017, compared to about 600,000 net new jobs added by firms with 500 or more employees.

${ }^{2}$ We define minorities as all groups other than non-Hispanic whites. Due to data limitations in the Small Business Credit Survey, this paper examines data only on non-Hispanic whites, non-Hispanic blacks, Hispanics, and Asian racial and ethnic groups.

${ }^{3}$ U.S. Census Bureau's Current Population Survey, 2007 and 2017.

${ }^{4}$ Authors' calculations based on U.S. Census Bureau's Annual Survey of Entrepreneurs, 2015 and Survey of Business Owners, 2012.

${ }^{5}$ Whenever we refer to small employer firms, we mean businesses with fewer than 500 employees.
} 


\section{Literature Review}

The economics and finance literatures provide compelling evidence that sufficient starting capital is a binding constraint for new firms. Access to capital, in general, is related to positive business outcomes. Fairlie and Robb (2008) found better capitalized businesses had higher sales, profits, and employment, and were less likely to close than businesses that received lower levels of start-up capital.

Previous research shows much of the financial capital used to start businesses comes from the owners themselves. For example, entry into entrepreneurship increases with sudden increases in personal wealth such as via bequest (Cagetti and De Nardi, 2006) or external change in taxation rates (Nanda, 2008) and with increased access to bank financing through deregulation and loosening of branching restrictions (Black and Strahan, 2002). Likewise, the absence of funds inhibits entry. For example, Evans and Jovanovic (1989) find borrowing capacity limits entrepreneurial entry; using the National Longitudinal Survey of Older and Young Men, they estimate new entrepreneurs are constrained in starting a new business by the size of their initial assets. Low levels of wealth and personal liquidity constraints can thus create substantial barriers to entry for would-be entrepreneurs because an owner then has little wealth to invest directly in a business or to use as collateral to obtain business loans or other financing. Lenders and investors frequently require a substantial level of investment from an owner's own capital to approve a loan or investment.

Racial and ethnic inequalities in personal wealth can thus translate into corresponding disparities in business creation and ownership. In fact, Fairlie (2006) found differences in asset levels are the largest single factor that explains racial disparities in business creation rates. U.S. Census Bureau 2013 estimates indicate half of all Hispanic households have less than $\$ 12,458$ in wealth, while half of all African American households have less than $\$ 9,211$ (see table 1). Wealth levels among non-Hispanic white households are much higher. African American household wealth levels are just 7 percent, and Hispanic household wealth levels total just 9.4 percent of non-Hispanic white household wealth levels. Only Asian households have wealth levels similar to those of non-Hispanic whites (85 percent). ${ }^{6}$ These wealth disparities increase for all but Hispanic households when we exclude home equity. Low levels of wealth among Hispanic- and African American households thus contribute to these groups having lower business creation rates relative to their representation in the U.S. population.

\footnotetext{
${ }^{6}$ Due to data limitations, we can only reference coarsely grained racial/ethnic groups; finer analysis might show significant wealth differences within these categories.
} 


\section{Table 1: Median Net Worth by Race and Hispanic Origin of Household}

\begin{tabular}{|c|c|c|c|c|}
\hline $\begin{array}{c}\text { Race and Hispanic Origin of } \\
\text { Household }\end{array}$ & $\begin{array}{c}\text { Median } \\
\text { net } \\
\text { worth }\end{array}$ & $\begin{array}{l}\text { Net worth } \\
\text { as a percent } \\
\text { of non- } \\
\text { Hispanic } \\
\text { white net } \\
\text { worth }\end{array}$ & $\begin{array}{l}\text { Median net } \\
\text { worth } \\
\text { (excluding } \\
\text { equity in own } \\
\text { home) }\end{array}$ & $\begin{array}{l}\text { Net worth as a } \\
\text { percent of non- } \\
\text { Hispanic white } \\
\text { net worth } \\
\text { (excluding } \\
\text { equity in own } \\
\text { home) }\end{array}$ \\
\hline White alone & $\$ 103,976$ & & $\$ 34,755$ & \\
\hline White alone, not Hispanic & $\$ 132,483$ & & $\$ 51,100$ & \\
\hline Black alone (Hispanic and not Hispanic) & $\$ 9,211$ & $7.0 \%$ & $\$ 2,725$ & $5.3 \%$ \\
\hline Asian alone & $\$ 112,250$ & $84.7 \%$ & $\$ 41,507$ & $81.2 \%$ \\
\hline Other & $\$ 13,703$ & $10.3 \%$ & $\$ 4,270$ & $8.4 \%$ \\
\hline Hispanic origin (any race) & $\$ 12,458$ & $9.4 \%$ & $\$ 5,825$ & $11.4 \%$ \\
\hline Not of Hispanic origin (any race) & $\$ 99,409$ & $75.0 \%$ & $\$ 33,699$ & $65.9 \%$ \\
\hline Total & $\$ 80,039$ & & $\$ 25,116$ & \\
\hline
\end{tabular}

Sources: U.S. Census Bureau's Wealth, Asset Ownership, and Debt of Households Detailed Tables, 2013 at https://www.census.gov/data/tables/2013/demo/wealth/wealth-asset-ownership.html

Few research efforts have focused on the related question of whether low levels of personal wealth and liquidity constraints also limit the ability of minority entrepreneurs to raise adequate levels of financial capital. The common use of personal commitments to obtain business loans suggests wealthier entrepreneurs may be able to negotiate better credit terms and obtain larger loans for their new businesses, potentially leading to more successful outcomes (Astebro and Berhardt, 2005). Cavalluzzo and Wolken (2005) found personal wealth, primarily through homeownership, increases access to capital by lowering the probability of loan denials among existing business owners.

We derive the most recent statistics on business ownership by race and ethnicity from the Census Bureau's 2015 Annual Survey of Entrepreneurs (ASE), released in 2017. As seen in table 2, nonHispanic white business owners made up about 80 percent of the employer business population in the United States in 2015 that was classifiable by race and ethnicity, yet they are 61.7 percent of the population. Black-owned businesses made up just 2.1 percent of the employer business population, but they are more than 12 percent of the U.S. population. Asian-owned businesses made up 10 percent of the employer business population, but they are only 5.4 percent of the U.S. population. Only non-white Hispanics had similar shares of employer businesses and overall U.S. population, at 1.6 percent. 
Table 2: Employer Firms by Race/Ethnicity (2015)

\begin{tabular}{|c|c|c|c|}
\hline Race or Ethnicity & $\begin{array}{c}\text { Number of } \\
\text { employer firms }\end{array}$ & $\begin{array}{l}\text { As percent of all } \\
\text { firms classifiable } \\
\text { by race/ethnicity }\end{array}$ & $\begin{array}{l}\text { Share of U.S. } \\
\text { population } \\
\text { (2015) }\end{array}$ \\
\hline White & $4,483,080$ & $85.5 \%$ & $77.1 \%$ \\
\hline Non-Hispanic white & $4,215,639$ & $80.4 \%$ & $61.7 \%$ \\
\hline Black or African American (non-Hispanic) & 108,007 & $2.1 \%$ & $12.4 \%$ \\
\hline Asian (non-Hispanic) & 526,863 & $10.0 \%$ & $5.4 \%$ \\
\hline Some other race (non-Hispanic) & 46,077 & $0.9 \%$ & $0.9 \%$ \\
\hline \multicolumn{4}{|l|}{ Hispanic } \\
\hline All & 312,738 & $6.0 \%$ & $17.6 \%$ \\
\hline White & 233,637 & $4.5 \%$ & $15.5 \%$ \\
\hline \multirow[t]{2}{*}{ Non-white } & 85,879 & $1.6 \%$ & $1.6 \%$ \\
\hline & \multicolumn{3}{|c|}{ As percent of all firms } \\
\hline All firms classifiable by race and ethnicity & $5,245,108$ & $94.8 \%$ & \\
\hline $\begin{array}{l}\text { Publicly held and other firms not } \\
\text { classifiable by gender, ethnicity, race, } \\
\text { and veteran status }\end{array}$ & 286,061 & $5.2 \%$ & \\
\hline All firms & $5,531,169$ & & \\
\hline
\end{tabular}

Sources: U.S. Census Bureau's 2015 Annual Survey of Entrepreneurs and U.S. Census Bureau Population Estimates Program, National Population by Characteristics: 2010-2017

Publicly held companies and other firms not classifiable by race and ethnicity made up just 5.2 percent of the total number of businesses. However, those firms generated almost two-thirds of the sales of all firms, and employed more than half of the workforce, as shown in table 3 . The largest of these firms, those with 500 or more employees, predominantly drive these numbers. These firms generated 57.5 percent of all sales, and employed 43.7 percent of workers at all employer firms. These larger, publicly traded companies and corporations thus make up a vast portion of the business economy.

In terms of both revenues and employment, minority-owned businesses comprise a disproportionately smaller share of the economy. As shown in table 3, black-owned businesses generated less than 1 percent of sales and less than 2 percent of employment in classifiable firms. Shares by Asian-owned firms were just 5.6 percent and 7.2 percent, respectively. Finally, non-white Hispanic-owned companies generated less than 1 percent of sales and 1.1 percent of employment. Clearly, minority-owned businesses are underrepresented in both the overall and the small employer business population (firms with fewer than 500 employees), and the minority-owned businesses themselves are relatively small in terms of both sales and employment. One reason for lower sales and employment levels could be that these businesses are facing greater challenges in obtaining sufficient financial capital, which we will examine in the next section. 


\section{Table 3: Employer Sales and Employment (2015)}

\begin{tabular}{|c|c|c|c|c|}
\hline Race or Ethnicity & $\begin{array}{l}\text { Sales, receipts, or } \\
\text { value of shipments } \\
(\$ 1,000 \mathrm{~s})\end{array}$ & $\begin{array}{l}\text { As a percent of all } \\
\text { firms classifiable by } \\
\text { race/ethnicity }\end{array}$ & $\begin{array}{l}\text { Number of paid } \\
\text { employees }\end{array}$ & $\begin{array}{l}\text { As a percent of all firms } \\
\text { classifiable by } \\
\text { race/ethnicity }\end{array}$ \\
\hline White & $\$ 10,636,612,110$ & $92.2 \%$ & $50,618,026$ & $89.1 \%$ \\
\hline Non-Hispanic white & $\$ 10,307,376,334$ & $89.3 \%$ & $48,349,944$ & $85.1 \%$ \\
\hline Black or African American (non-Hispanic) & $\$ 96,186,349$ & $0.8 \%$ & 978,984 & $1.7 \%$ \\
\hline Asian (non-Hispanic) & $\$ 648,882,910$ & $5.6 \%$ & $4,106,102$ & $7.2 \%$ \\
\hline Some other race (non-Hispanic) & $\$ 56,564,863$ & $0.5 \%$ & 342,861 & $0.6 \%$ \\
\hline \multicolumn{5}{|l|}{ Hispanic } \\
\hline All & $\$ 359,509,973$ & $3.1 \%$ & $2,572,873$ & $4.5 \%$ \\
\hline White & $\$ 290,325,639$ & $2.5 \%$ & $1,993,302$ & $3.5 \%$ \\
\hline \multirow[t]{2}{*}{ Non-white } & $\$ 75,661,461$ & $0.7 \%$ & 624,890 & $1.1 \%$ \\
\hline & \multicolumn{2}{|c|}{ As a percent of all firms } & \multicolumn{2}{|r|}{ As a percent of all firms } \\
\hline All firms classifiable by race and ethnicity & $\$ 11,536,757,021$ & $34 \%$ & $56,782,110$ & $48 \%$ \\
\hline Publicly held and other firms not & & & & \\
\hline $\begin{array}{l}\text { classifiable by gender, ethnicity, race, } \\
\text { and veteran status }\end{array}$ & $\$ 22,060,879,500$ & $66 \%$ & $61,619,917$ & $52 \%$ \\
\hline All firms & $\$ 33,597,636,521$ & & $118,402,027$ & \\
\hline
\end{tabular}

Source: U.S. Census Bureau's 2015 Annual Survey of Entrepreneurs

Much of the previous research on the credit market experiences of minority-owned businesses used data from various years of the Federal Reserve Board of Governors' Survey of Small Business Finances. The main finding from this literature is that minority business enterprises experience higher loan denial probabilities and pay higher interest rates than white-owned businesses, even after controlling for differences in creditworthiness and other factors (Blanchard et al. 2004, Blanchflower et al. 2002, Coleman 2003, Mitchell and Pearce 2004). Cavalluzzo and Wolken (2005) found that while greater personal wealth is associated with a lower probability of denial, even after controlling for personal wealth, there remained a large difference in denial rates across demographic groups. African Americans, Hispanics, and Asians were all more likely to be denied credit compared with whites, even after controlling for a number of owner and firm characteristics, including credit history, credit score, and wealth. They also found Hispanics and African Americans were more likely to pay higher interest rates on the loans they obtained.

Bates and Robb (2015a; 2015b), using the Kauffman Firm Survey data (described in the following section), find minority-owned firms encounter discriminatory practices by banks, which limits credit availability. They find minority-owned businesses feel discouraged from seeking bank loans because they fear their applications will be turned down. Owner race and wealth both powerfully shape loan access: high wealth opens doors, while minority ownership closes them. Similarly, Fairlie, Robb, and Robinson (2016) find black-owned start-ups face more difficulty in raising external capital, especially external debt. They find disparities in creditworthiness constrain black entrepreneurs, but perceptions of treatment by banks also hold them back. Black entrepreneurs apply for bank loans less often than white entrepreneurs largely because they expect to be denied credit, even in settings where strong local banks favor new business development. 
Separately, Chatterji and Seamans (2012) find that the expansion of credit card availability stimulated entry into entrepreneurship especially for black entrepreneurs, and find the strongest results in areas with high rates of historical racial discrimination. However, such credit products can carry relatively high costs. Undercapitalization of minority-owned firms is widely recognized as a major determinant of their lower profits and higher closure rates, in comparison to white-owned businesses (see Bates, 1997; Fairlie and Robb, 2008). The lower levels of financial capitalization typifying minorityowned firms are "the single most important fact explaining racial differences in business outcomes" (Fairlie and Robb, 2008, page 130).

As the minority population continues to rise, it is more important than ever that these prospective business owners have the resources they need not only to launch but also to grow. Because banks have historically provided young firms with crucial growth capital (Berger and Udell, 1995; Robb and Robinson, 2014) and have played a substantial role in new firm formation and business expansion in the United States (Kerr and Nanda, 2009), minority businesses' experiences with financial institutions in the credit market are especially important. 


\section{About the Data}

Access to timely data on small business financing, especially by owner demographics, has been a challenge. Much recent research has relied on the four iterations of the Federal Reserve's Survey of Small Business Finances $(1987,1993,1998$, and 2003). Although these surveys provided large samples of businesses of all ages, they tended to underrepresent younger firms and the data were released with a long lag. The Fed discontinued the survey after 2003 , so there were no data available on small business financing from the Federal Reserve during the 2008 financial crisis.

More recent work on this topic utilized the Kauffman Firm Survey, which is a longitudinal survey of new businesses in the United States, collecting annual information over the 2004 to 2011 period for a sample of 4,928 firms that began operations in 2004. The underlying sample frame for the Kauffman Firm Survey is Dun and Bradstreet data. The Kauffman Firm Survey data contain unprecedented detail on the financing patterns of start-ups as well as detailed information on both the firm itself and up to 10 business owners of the firm. The Kauffman Firm Survey is the only large, nationally representative, longitudinal data set that provides detailed information on new firms and their financing activities. However, at the time of the financial crisis, the data set's firms were all about four years old. Therefore, there was no comprehensive way to gauge how the crisis affected start-ups during that time period or, for that matter, small firms of any other ages.

As a result, our understanding of the current financing patterns and credit market experiences of small businesses has been quite limited and based on anecdotes, out of date data, or data that do not fully cover the small business population. However, new efforts have emerged that will allow us to better understand the financing challenges faced by small businesses, and minority businesses, in particular. The U.S. Census Bureau conducts the Survey of Business Owners (SBO) every five years (in years ending in two and seven), but the kinds of financing questions covered in the survey have historically been very limited. The Census Bureau started a new initiative in 2014, the Annual Survey of Entrepreneurs (ASE), which examines employer businesses and provides more timely data (the first survey was released in 2016). That effort is now in its third year and will be combined with and continued under a new survey effort called the Annual Business Survey, which will replace the ASE and the SBO, and started collecting data in the 2017 survey year. The Annual Business Survey contains more detailed questions on financing and credit market experiences, which follows the questioning in the ASE. One limitation with these data is that public access is limited to published tabulations that provide only summary statistics of businesses broken out by firm size, age, and industry.

This paper relies on another data collection effort that has emerged recently. Much of the data used for our research is derived from the 2016 Small Business Credit Survey (SBCS), a collaborative effort by the Community Development Offices of the 12 regional Federal Reserve Banks, fielded in the third and fourth quarters of 2016. A small subset of regional Federal Reserve Banks conducted earlier versions of the survey. The 2016 SBCS is the first survey effort in which all 12 banks in the Federal Reserve System participated, with a sample drawn from all 50 states and the District of Columbia. 
The survey asked respondents about their companies and their credit market experiences over the prior 12 -month period. The survey yielded 7,916 responses from employer firms with fewer than 500 fulltime employees in 50 states and the District of Columbia. ${ }^{7}$ It includes information on the race or ethnicity of the business owner(s). We use these data to explore the financing patterns and credit market experiences of small employer businesses ${ }^{8}$ by detailed owner demographics.

In this paper, we primarily use four mutually exclusive race/ethnicity categories: white, black or African American, Asian or Pacific Islander, and Hispanic. ${ }^{9}$ The survey asked respondents the following question about the race and ethnicity of the owner(s):

"What percentage of your business is owned and controlled by an owner(s) who is (are): Please slide the appropriate bar to indicate the percentage. NOTE: Percentages must sum to 100.

Asian or Pacific Islander?
African American?
Hispanic, Latino, or Spanish?
Native American?
White?"

If a respondent identifies business ownership as greater than 50 percent "Asian or Pacific Islander," the firm is categorized as an Asian-owned firm. If business ownership is greater than 50 percent "African American," the firm is classified as an African American- or black-owned firm, and so on. For statistics reported only by minority status, a firm is identified as nonminority-owned if business ownership is greater than 50 percent white or if the firm is equally owned by white and minority individuals. The firm is identified as minority-owned if Asian, African American, Hispanic, or Native American individuals own more than 50 percent of the business.

The 2016 SBCS uses a convenience sample of establishments and employs weights to attempt to reflect the full population of small businesses in the United States. Although convenience samples are nonrandom and thus not generalizable to the small business population as a whole, the new SBCS data provide sufficient sample sizes of minority-owned firms to allow for a more in-depth exploration of the current credit market experiences of firms by race and ethnicity than was previously possible. The new data offer unique insights into these important and growing segments of the small business population.

\footnotetext{
${ }^{7}$ The survey also yielded responses from nonemployer firms, but we did not examine them in this paper.

${ }^{8}$ Hereafter, small employer businesses are firms with between 1 and 499 employees.

${ }^{9}$ Hereafter, whenever we report data on white or black ownership of a small business in text, tables, or charts, we refer to non-Hispanic white and non-Hispanic black data. Whenever we report figures on Asian-owned firms, we refer to non-Hispanic Asian or non-Hispanic Pacific Islander.
} 
As shown in table 4, black- and Hispanic-owned businesses are overrepresented in this survey effort compared with the general small business population, which allows us sufficient sample sizes to rigorously examine these two groups separately. This is important because previous research has shown these two specific groups to be most disadvantaged in credit markets, compared with businesses owned by whites and Asians (Fairlie and Robb, 2008; Bates and Robb, 2013).

\section{Table 4: Small Employer Firms by Race/Ethnicity10 11}

\begin{tabular}{lrrrrr} 
& Asian & Black & Hispanic & White & \multicolumn{1}{c}{$\mathbf{N}$} \\
\hline SBCS unweighted sample* & $5 \%$ & $10 \%$ & $6 \%$ & $79 \%$ & $\mathbf{7 , 6 5 6}$ \\
\hline Census Data & $10 \%$ & $2 \%$ & $2 \%$ & $87 \%$ & $\mathbf{4 , 9 6 3 , 6 5 6}$ \\
\hline
\end{tabular}

Sources: Survey of Business Owners (2012) and Small Business Credit Survey (2016)

Businesses are contacted by email through a diverse set of organizations that serve the small business community. ${ }^{12}$ One of the Federal Reserve Banks contacts prior SBCS participants and small businesses on publicly available email lists. ${ }^{13}$ The survey instrument was an online questionnaire that typically took respondents 6 to 12 minutes to complete, depending upon the intensity of a firm's search for financing. The questionnaire uses question branching and flows based upon responses to survey questions. For example, financing applicants receive a different line of questioning than nonapplicants. Therefore, the number of observations for each question varies according to how many firms are asked and complete a particular question.

\section{Descriptive Statistics from the 2016 Small Business Credit Survey}

The left side of figure 1 shows black- and Hispanic-owned employer firms had the highest application rates for credit at 53 percent and 50 percent, respectively. This compares with 46 percent for Asian- and 43 percent for white-owned businesses. The most commonly cited reason for applying across all racial and ethnic categories was to expand the business, with about 70 percent of each of the

\footnotetext{
${ }^{10}$ Native American-owned small employer firms made up about 1 percent of the unweighted responses to the SBCS, compared with slightly less than half a percent in the 2012 Survey of Business Owners.

${ }^{11}$ We obtained tables 4 through 6 as well as figures 1 through 5 directly from the 2016 Small Business Credit Survey: Report on Minority-Owned Firms.

12 For a full list of community partners, see the 2016 Small Business Credit Survey: Report on Minority-Owned Firms, pages 24-26.

${ }^{13}$ These lists include the System for Award Management (SAM) Entity Management Extracts Public Data Package, the Small Business Administration (SBA) Dynamic Small Business Search (DSBS), state-maintained lists of certified disadvantaged business enterprises (DBEs), state and local government procurement vendor lists, state and local government-maintained lists of small or disadvantaged small businesses, and a list of veteran-owned small businesses maintained by the U.S. Department of Veterans Affairs.
} 
minority categories citing this reason, and about 60 percent of white-owned businesses citing this reason. Black-owned businesses were the most likely to cite the payment of operating expenses as a reason (60 percent), while white-owned businesses were the least likely (40 percent). Hispanic-owned firms were the most likely to cite refinancing as a reason for applying (30 percent), but this was cited by just 15 to 25 percent by other racial groups, distinctly lower than the two primary reasons.



Source: 2016 Small Business Credit Survey: Report on Minority-Owned Firms

In terms of outcomes, only 61 percent of black-owned businesses received at least some of the financing requested, compared with 80 percent of white-owned businesses. (See the left column in table 5.) About three-quarters of Hispanic- and Asian-owned businesses received at least some of the financing they requested. Some of the lower approval rates for minority businesses might reflect differences in credit risk or other factors. Due to limited sample sizes, the minority groups are combined to allow for a comparison in financing approval rates by credit score categories. ${ }^{14}$ As shown in the righthand column of table 5, there is a 10-percentage point gap in financing approval rates between low-risk minority- and nonminority-owned businesses ( 75 percent versus 85 percent). Although overall approval rates are lower for higher-risk businesses, the racial gap is smaller (6 percentage points). Some 65 percent of medium- and high-credit-risk companies that were nonminority-owned received at least part of the financing applied for, compared with 59 percent of minority-owned firms.

\footnotetext{
${ }^{14}$ The categories are self-reported business credit score or personal credit score, depending on which is used to obtain financing for their business. If the firm uses both, the highest risk rating is used. "Low credit risk" is an 80100 business credit score or 720+ personal credit score. "Medium credit risk" is a 50-79 business credit score or a 620-719 personal credit score. "High credit risk" is a 1-49 business credit score or a less than 620 personal credit score.
} 


\section{Table 5: Application Outcomes, by Race/Ethnicity}

\section{SHARE RECEIVING AT LEAST SOME FINANCING}

Percent of applicants

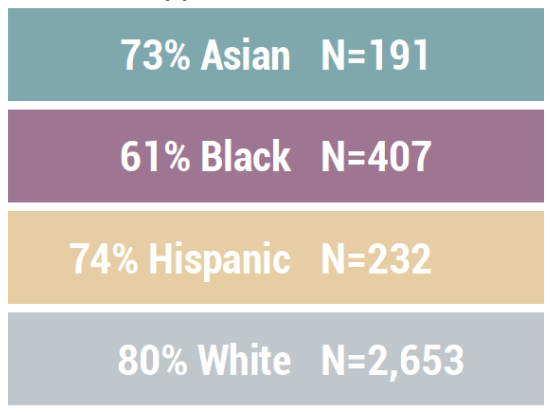

\section{SHARE RECEIVING AT LEAST SOME} FINANCING BY CREDIT RISK

\begin{tabular}{lcc}
\hline Low Credit Risk & $\begin{array}{c}\text { \% of } \\
\text { applicants }\end{array}$ & $\mathrm{N}$ \\
\hline nonminority & $85 \%$ & 1,689 \\
\hline minority & $75 \%$ & 404 \\
\hline $\begin{array}{l}\text { Medium or High } \\
\text { Credit Risk }\end{array}$ & $\begin{array}{c}\% \text { of } \\
\text { applicants }\end{array}$ & $\mathrm{N}$ \\
\hline nonminority & $65 \%$ & 508 \\
\hline minority & $59 \%$ & 352 \\
\hline
\end{tabular}

Source: 2016 Small Business Credit Survey: Report on Minority-Owned Firms

Of the 75 percent of minority-owned businesses considered low credit risk approved for at least some of the financing they sought, only 40 percent were approved for their entire financing ask. In contrast, 68 percent of the low-risk nonminority-owned firms that were approved for at least some of the financing they sought were approved for their ask in full (see figure 2). For the medium- or high-risk minority-owned businesses, only 21 percent of those that requested financing received all of what they applied for, compared with nearly a third (32 percent) of nonminority-owned firms.

Figure 2: Financing Approved by Credit Risk, by Minority/Nonminority Status

\begin{tabular}{|c|c|c|c|}
\hline \multicolumn{3}{|c|}{ TOTAL FINANCING APPROVED BY CREDIT RISK* (Percent of Approved) } & \multirow{3}{*}{$\begin{array}{l}\text { Full financing } \\
\text { approved } \\
\text { Partial financing } \\
\text { approved }\end{array}$} \\
\hline & \multicolumn{2}{|l|}{ Low risk } & \\
\hline Nonminority $\mathrm{N}=1,489$ & $68 \%$ & $32 \%$ & \\
\hline \multirow[t]{2}{*}{ Minority $N=313$} & $40 \%$ & $60 \%$ & \\
\hline & \multicolumn{2}{|l|}{ Medium or high risk } & \\
\hline Nonminority $\mathrm{N}=336$ & $32 \%$ & $68 \%$ & \\
\hline Minority $N=209$ & $21 \%$ & $79 \%$ & \\
\hline
\end{tabular}

Source: 2016 Small Business Credit Survey: Report on Minority-Owned Firms 
The above table translates into a large proportion of minority-owned firms that face a variety of challenges in obtaining financing, even among those deemed to have a low credit risk. Table 6 shows the percentage of employer firms that cited a variety of financial challenges by both owner race/ethnicity as well as by firm revenues (under $\$ 1$ million in revenues and more than $\$ 1$ million in revenues). Blackowned businesses with less than $\$ 1$ million in revenues were twice as likely as their white-owned counterparts to say they faced challenges in obtaining funds for expansion (62 percent versus 31 percent). Even for black-owned firms with more than $\$ 1$ million in revenues, more than half (53 percent) said obtaining funds for expansion was a challenge, compared with less than a quarter (23 percent) of white-owned firms with more than $\$ 1$ million in revenues. In comparison, fewer than half of Asian- and Hispanic-owned businesses with less than $\$ 1$ million in revenues cited this as a challenge, compared with about 30 percent of those with more than $\$ 1$ million in revenues.

In terms of credit availability, 58 percent of black-owned businesses and 45 percent of Hispanicowned businesses with revenues below $\$ 1$ million stated this was a challenge, compared with just 32 percent of similarly sized white-owned firms. The gap for businesses with more than \$1 million of revenues across the groups was similar. Nearly half of black-owned businesses with more than $\$ 1$ million in revenues stated credit availability was a challenge, compared with less than a quarter of white-owned businesses. More than a third of Hispanic- and Asian-owned businesses in this larger revenue class cited this challenge, compared with 45 percent of Hispanic- and 42 percent of Asianowned businesses in the lower revenue group. 
Table 6: Financial Challenges by Size of Firm (Past 12 Months)

\begin{tabular}{|c|c|c|c|c|}
\hline $\begin{array}{l}\text { FINANCIAL CHALLENG } \\
\text { Percent of employer firms } \\
<\$ 7 \mathrm{M} \text { in revenues }\end{array}$ & BY SIZE & FIRM & Hispanic & White \\
\hline Funds for expansion & $45 \%$ & $62 \%$ & $47 \%$ & $31 \%$ \\
\hline Credit availability & $42 \%$ & $58 \%$ & $45 \%$ & $32 \%$ \\
\hline Operating expenses & $49 \%$ & $49 \%$ & $43 \%$ & $39 \%$ \\
\hline Debt payments & $34 \%$ & $33 \%$ & $30 \%$ & $27 \%$ \\
\hline Fulfill contracts & $23 \%$ & $28 \%$ & $26 \%$ & $17 \%$ \\
\hline None of these & $25 \%$ & $18 \%$ & $23 \%$ & $38 \%$ \\
\hline $\mathbf{N}$ & 200 & 570 & 268 & 2,727 \\
\hline $\begin{array}{l}\text { Percent of employer firms } \\
\geq \$ 7 M \text { in revenues }\end{array}$ & Asian & Black & Hispanic & White \\
\hline Funds for expansion & $31 \%$ & $53 \%$ & $28 \%$ & $23 \%$ \\
\hline Credit availability & $38 \%$ & $49 \%$ & $34 \%$ & $24 \%$ \\
\hline Operating expenses & $27 \%$ & $39 \%$ & $31 \%$ & $26 \%$ \\
\hline Debt payments & $15 \%$ & $33 \%$ & $22 \%$ & $17 \%$ \\
\hline Fulfill contracts & $14 \%$ & $15 \%$ & $17 \%$ & $11 \%$ \\
\hline None of these & $46 \%$ & $28 \%$ & $47 \%$ & $55 \%$ \\
\hline $\mathbf{N}$ & 166 & 172 & 177 & 3,077 \\
\hline
\end{tabular}

Source: 2016 Small Business Credit Survey: Report on Minority-Owned Firms

With only one exception, black-, Hispanic-, and Asian-owned businesses were more likely to cite the financial challenges listed in table 6 than businesses owned by whites, regardless of their revenue size. ${ }^{15}$ These challenges can have negative effects on these businesses. As shown in figure 3 , some of the actions taken by the companies that experience these challenges include relying on personal funds (around 75 percent to 85 percent of firms), making late payments (about 40 percent to 53 percent), and taking on more debt (about 37 percent to 49 percent of firms). Between 40 percent and 50 percent of companies responded to these financing challenges by cutting staff.

${ }^{15}$ A slightly lower percentage of Asian-owned businesses with over $\$ 1$ million in revenues reported facing challenges with making debt payments than did white-owned firms of a similar revenue size. (The percentages were 15 percent and 17 percent, respectively). 
Figure 3: Actions Taken as a Result of Challenges, by Race/Ethnicity

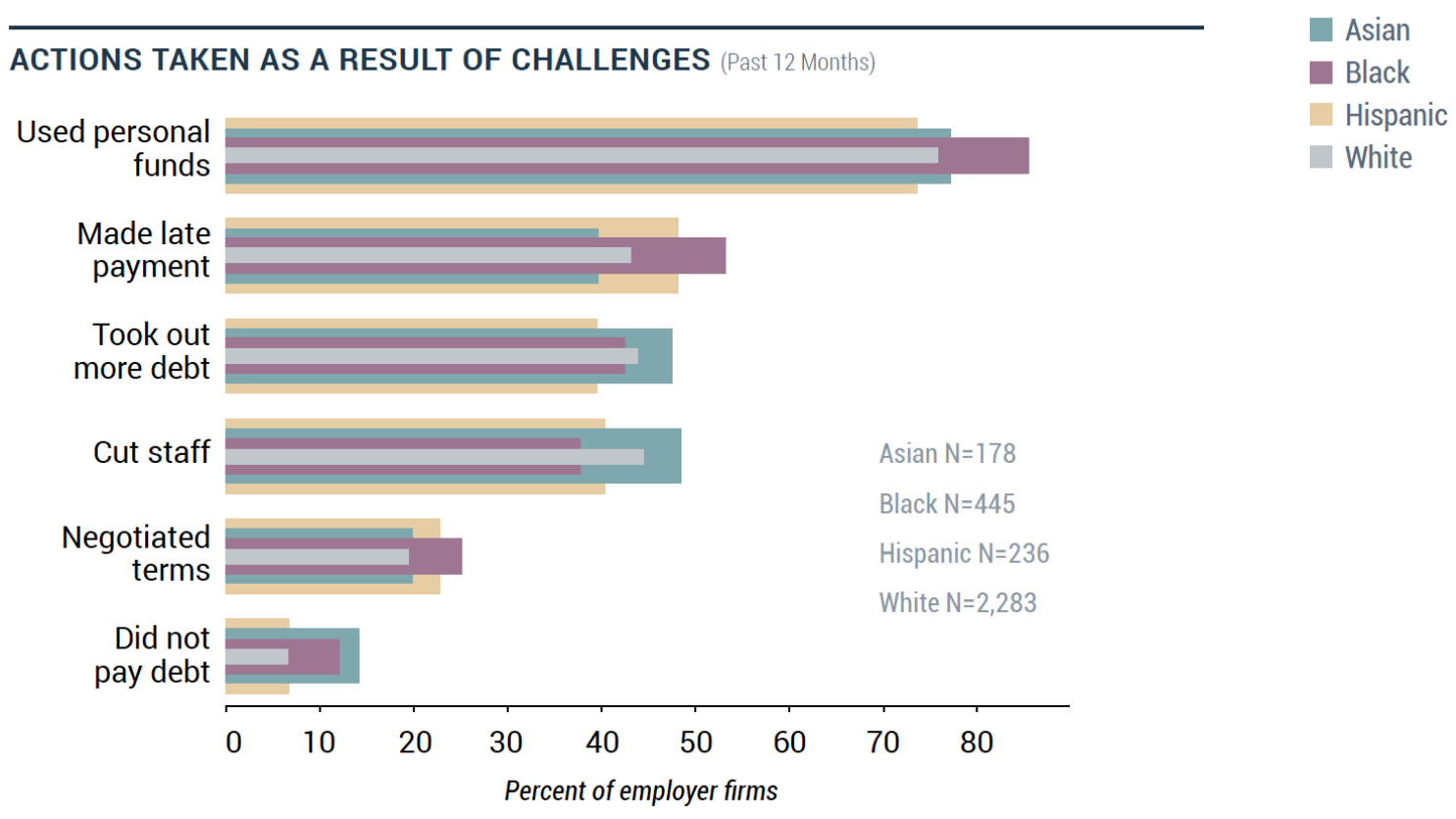

Source: 2016 Small Business Credit Survey: Report on Minority-Owned Firms

Nearly half of black-owned firms and one-third of Hispanic-owned firms cited their credit score as a reason for experiencing a financing shortfall, compared with about a quarter of Asian- and whiteowned firms (see figure 4). Black and Hispanic business owners were also more likely to cite a lack of sufficient collateral as a reason (37 percent and 43 percent, respectively), compared with less than a third of businesses owned by whites and Asians. Business performance and debt levels were cited most by Asian-owned businesses ( 38 percent and 35 percent, respectively), while Hispanics and blacks cited credit history most ( 33 percent and 30 percent respectively). While black-owned firms were most likely to cite perceived unfair lending practices, just 8 percent of those firms actually cited this reason. 


\section{Figure 4: Reasons for Credit Denial, by Race/Ethnicity}

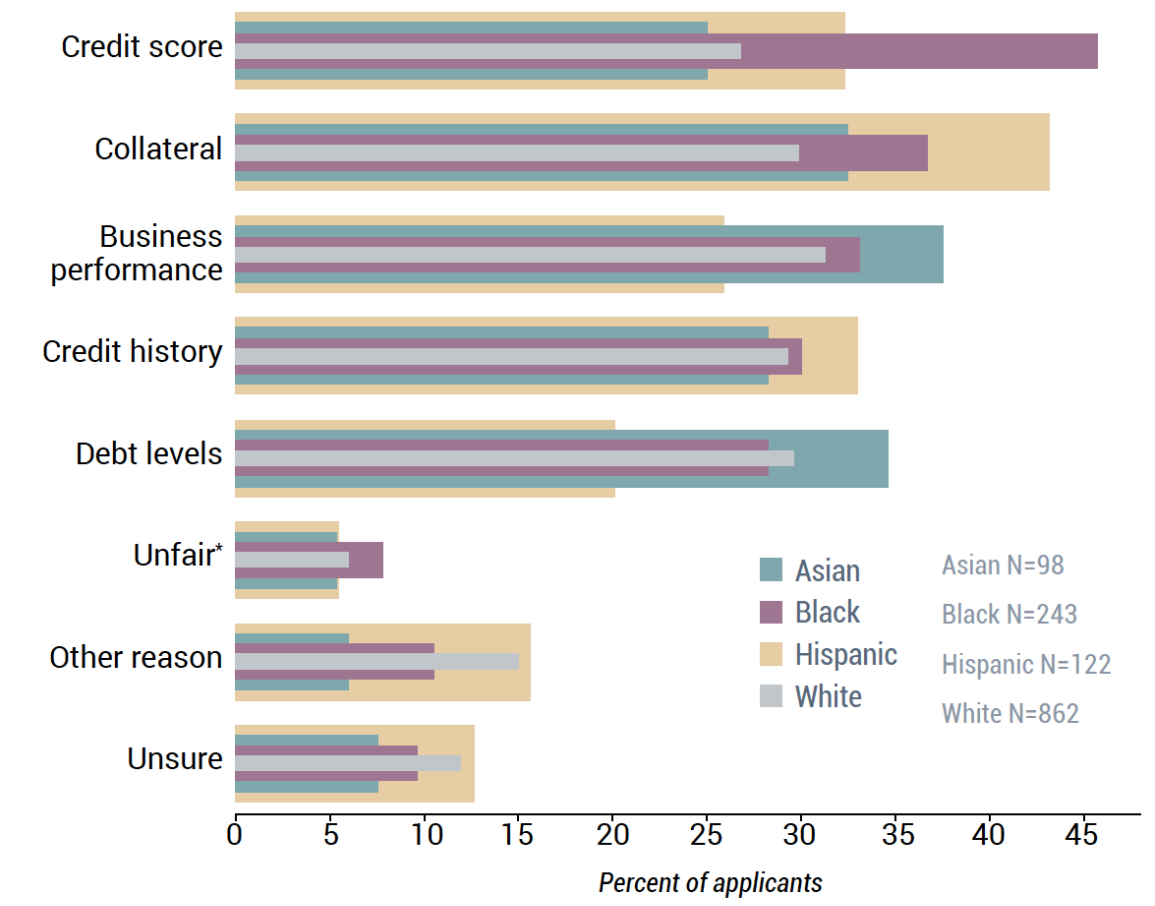

* "Unfair" refers to perceived unfair lending practices.

Source: 2016 Small Business Credit Survey: Report on Minority-Owned Firms

Interestingly, nearly 40 percent of black small business owners who did not apply for financing stated they did not do so because they felt discouraged about the likelihood of getting approval (see figure 5). About 21 percent of Hispanic- and Asian-owned companies said feeling discouraged was the primary reason for not applying for funding, compared with about 14 percent of businesses owned by whites. Only 22 percent of black-owned small businesses stated they did not apply for financing because they had sufficient financing, compared with 32 percent of Hispanic-, 37 percent of Asian-, and 52 percent of white-owned firms. 


\section{Figure 5: Primary Reason for Not Applying, by Race/Ethnicity}

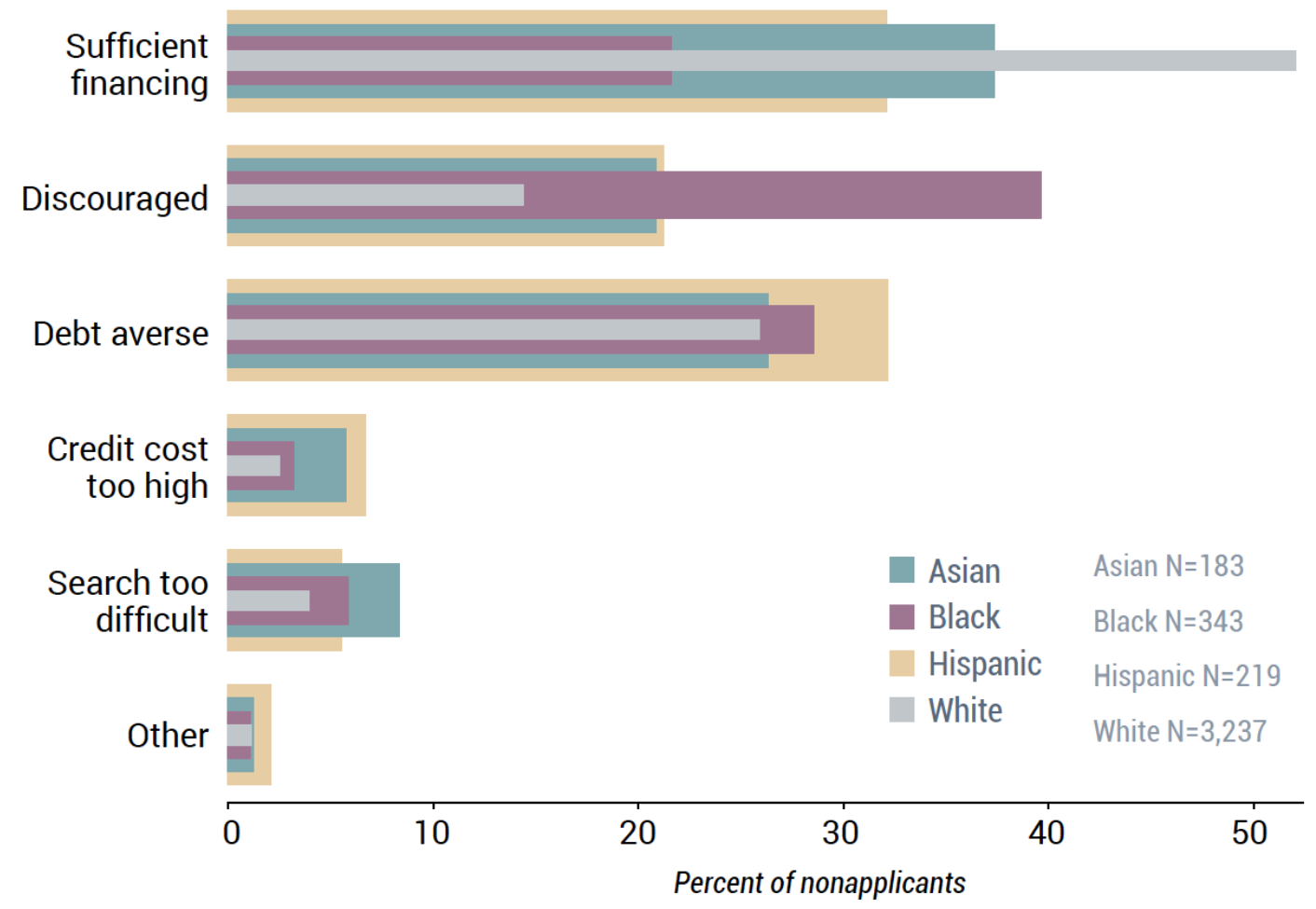

Source: 2016 Small Business Credit Survey: Report on Minority-Owned Firms

Overall, the snapshot described above shows minority-owned businesses face greater challenges in obtaining financing than their nonminority-owned counterparts. For Hispanic and black business owners, these challenges are particularly large. Given their lower wealth levels (see table 1), these two groups would be even more reliant on outside financing than Asian and white business owners, who, on average, have significantly higher wealth levels. The next section delves deeper into the challenges of obtaining financing, and examines the racial and ethnic gaps in credit market outcomes by a number of firm characteristics as well as through a series of multivariate analyses. 


\section{A Deeper Look at Minority-0wned Business Credit Market Experiences}

In this section, we use the 2016 Small Business Credit Survey data to delve deeper into a number of minority-owned business credit market experiences: being approved for financing, feeling discouraged from applying, applying for and being approved for financing through online lenders (such as OnDeck and Kabbage), and being satisfied with a lender. For each we will first analyze racial and ethnic gaps by various firm characteristics, and then we will examine the racial and ethnic effects in a multivariate setting, by introducing an increasing number of controls over the various model specifications. These controls include credit risk profiles (based on self-reported personal and business credit scores), whether a firm is profitable, the size of a firm in terms of employees and revenues, the industry and age of a firm, and other factors such as the gender and veteran status of a firm's owner and a business's geographic location.

To examine more rigorously the relationship between race and ethnicity of a firm's ownership and the dependent variables listed above, we use a series of multivariate logistic regressions using increasingly expansive sets of explanatory variables. We display the results as average marginal effects in tables $8,10,12,14$, and 16 and display the standard errors in parentheses. These marginal effects show the differential in the likelihood of the dependent variable occurring for changes in the value of an independent variable. In this case, the marginal effect displays the percentage point difference in the likelihood of the various scenarios occurring for three different groups of minority-owned firms (black-, Hispanic-, and Asian-owned) compared to white-owned firms. For example, from column one in table 8, one can surmise that Hispanic-owned firms are 10.2 percent less likely to get approved for financing than white-owned firms (though this differential disappears when other variables such as a firm's credit profile are controlled for).

Column one provides results from simply regressing race and ethnicity on the dependent variable, employing no additional controls. Column two presents findings from the next model specification, which adds controls for revenues, firm age, and firm industry. ${ }^{16}$ Column three presents the results from the third model specification, which adds in the additional control of credit risk. Finally, the results in column four control for a number of additional variables, including rural location, location in a low- or moderate-income area, whether the firm is profitable or not, employment size, owner veteran status, and owner gender.

To minimize confusion when comparing estimates reported in this section, we continue to report weighted estimations for the descriptive firm characteristics in this section. However, the multivariate results in this section are unweighted logistic regressions. There is some disagreement in the literature on whether or not to use sample weights in multivariate logistic estimation. Following the diagnostics of Solon et al. (2015), the unweighted results actually appear to be the most reliable

\footnotetext{
${ }^{16}$ Full regression results are in the appendix.
} 
estimates in our case. ${ }^{17}$ We provide the weighted regression results in the appendix for comparison purposes. ${ }^{18}$

\section{Loan approval}

Overall, white business owners have the highest loan approval rates at 80.2 percent, while black business owners have the lowest approval rates at 61.2 percent (see table 7). Asian and Hispanic owners' loan approval percentages fall in between these groups with rates of 73.2 percent and 73.9 percent, respectively. The racial gap in approval rates between white and black small business owners narrows for larger firms (in terms of revenues) as well as for older, more profitable firms, but large differentials between black- and white-owned firms persist. However, the racial gaps were relatively greater for the lower revenue, younger, high credit risk, and unprofitable firms. In general, approval rates for both Asian- and Hispanic-owned businesses were lower for most types of firms, compared with businesses owned by whites. While the Hispanic-white gap was smaller than the black-white business gap, it was larger than the Asian-white gap. The gap between Hispanic- and white-owned firms was largest for firms that were less than 5 years old at 7.2 percentage points.

\footnotetext{
${ }^{17}$ We did not detect heteroscedasticity. A likely correlation between the sampling criteria and error term with respect to minority-owned firms (that is, endogenous sampling) is addressed by controlling for additional strata (age, industry, size, geographic location) in the estimating equation. These strata also vary with the sampling probability. There are no conventionally accepted methods to test for heteroscedasticity in a logit model (Williams, 2009), but when comparing likelihood-based standard errors to robust standard errors on the base logit model results (not the results for average marginal effects, reported in this section), they are nearly identical, which suggests heteroscedasticity likely is not a significant problem.

${ }^{18}$ The standard errors tend to increase when adding weights to the models, and in some cases, they are over twice as large, compared with standard errors in the unweighted models. Regardless, our main results on the effect of black business ownership on overall approval and discouragement remain unchanged whether or not weights are used, but the statistical significance of the coefficient of Hispanic business ownership disappears as additional controls are placed in the weighted models, compared with the unweighted models. There are also some differences in the models for online application and approval, with the statistical significance of the coefficient of black ownership disappearing more quickly in the weighted versus unweighted versions. That is likely due to larger standard errors in the weighted models, which reflects less precise estimates about the effects of minority ownership.
} 


\section{Table 7: Loan Approval Rates}

\begin{tabular}{lccccc} 
Approved for Financing & White & Black & Asian & Hispanic & All \\
\hline ALL & $80.2 \%$ & $61.2 \%$ & $73.2 \%$ & $73.9 \%$ & $77.2 \%$ \\
& & & & & \\
<1 M & $75.5 \%$ & $58.8 \%$ & $66.8 \%$ & $71.6 \%$ & $72.2 \%$ \\
> 1M in revenues & $86.5 \%$ & $78.5 \%$ & $85.6 \%$ & $83.2 \%$ & $85.8 \%$ \\
& & & & & \\
< 5 years old & $77.2 \%$ & $51.6 \%$ & $73.0 \%$ & $70.0 \%$ & $72.9 \%$ \\
5+ years old & $81.8 \%$ & $69.7 \%$ & $73.4 \%$ & $77.0 \%$ & $79.9 \%$ \\
& & & & & \\
Low credit risk & $85.2 \%$ & $74.5 \%$ & $68.6 \%$ & $79.7 \%$ & $83.4 \%$ \\
Medium credit risk & $66.9 \%$ & $62.3 \%$ & $73.3 \%$ & $65.8 \%$ & $66.4 \%$ \\
High credit risk & $55.2 \%$ & $42.1 \%$ & $58.5 \%$ & $59.2 \%$ & $50.3 \%$ \\
& & & & & \\
Not profitable & $73.8 \%$ & $54.2 \%$ & $70.4 \%$ & $71.2 \%$ & $70.6 \%$ \\
Profitable & $84.9 \%$ & $73.7 \%$ & $75.8 \%$ & $77.8 \%$ & $83.0 \%$
\end{tabular}

Source: Authors' calculations based on data from the 2016 Small Business Credit Survey

The regression predicts the probability a firm is approved for at least some of the financing it applies for. The results are in table 8 . First, the credit risk and profitability controls behave the way one would expect, with higher-risk firms significantly less likely to be approved, compared with those with the lowest credit risk, and with profitable firms more likely to be approved than those that are not profitable. ${ }^{19}$

While the coefficients on the race and ethnicity variables are negative in all of the models, indicating each group is less likely to be approved than white-owned firms, the difference for Hispanicowned firms is only statistically significant in the first two models, but not after introducing the full set of controls. The coefficient for Asian owners is no longer statistically significant after adding the initial set of controls. Only the coefficient on black-owned firms remains statistically significant in all of the four models presented. We find that black-owned firms are about 5 percent less likely to get approval for financing than are white-owned firms, even after controlling for factors such as credit risk and the firm's age, size, industry, profitability, and employment. This finding is consistent with earlier research that examined the Survey of Small Business Finances and the Kauffman Firm Survey data.

\footnotetext{
${ }^{19}$ In the fourth model specification, firms with medium risk are, on average, 14 percent less likely to be approved for financing, compared with low-risk firms, while high-risk firms are 19 percent less likely to be approved.

Profitable firms are, on average, 8 percent more likely to be approved for financing, compared with firms that are unprofitable.
} 
At the August 2018 Minority Business Development Agency's national training conference in Philadelphia, participants highlighted various factors that contribute to this persistent gap in financing approval rates between black- and white-owned firms. The variety of factors mentioned included access to networks, business management knowledge and capacity, financial literacy, implicit and explicit biases, and, for immigrant-owned firms, language barriers.

\section{Table 8: Approved for Financing}

\begin{tabular}{|c|c|c|c|c|}
\hline Variables & (1) & $(2)$ & (3) & (4) \\
\hline Black & $\begin{array}{c}-0.182 * * * \\
(0.025)\end{array}$ & $\begin{array}{c}-0.105^{* * *} \\
(0.023)\end{array}$ & $\begin{array}{c}-0.057 * * * \\
(0.022)\end{array}$ & $\begin{array}{c}-0.048 * * \\
(0.022)\end{array}$ \\
\hline Asian & $\begin{array}{c}-0.066^{* *} \\
(0.031)\end{array}$ & $\begin{array}{l}-0.045 \\
(0.030)\end{array}$ & $\begin{array}{l}-0.045 \\
(0.030)\end{array}$ & $\begin{array}{l}-0.029 \\
(0.029)\end{array}$ \\
\hline Hispanic & $\begin{array}{c}-0.102 * * * \\
(0.030)\end{array}$ & $\begin{array}{c}-0.067 * * \\
(0.028)\end{array}$ & $\begin{array}{c}-0.044 * \\
(0.027)\end{array}$ & $\begin{array}{l}-0.038 \\
(0.026)\end{array}$ \\
\hline Race not reported & $\begin{array}{r}-0.088^{*} \\
(0.048)\end{array}$ & $\begin{array}{l}-0.043 \\
(0.044)\end{array}$ & $\begin{array}{l}-0.032 \\
(0.043)\end{array}$ & $\begin{array}{l}-0.032 \\
(0.043)\end{array}$ \\
\hline Firm age & $\mathrm{N}$ & $Y$ & $\mathrm{Y}$ & $\mathrm{Y}$ \\
\hline Firm industry & $\mathrm{N}$ & $Y$ & $\mathrm{Y}$ & $\mathrm{Y}$ \\
\hline Firm size (revenues) & $\mathrm{N}$ & $Y$ & $Y$ & $\mathrm{Y}$ \\
\hline $\begin{array}{l}\text { Credit risk } \\
\text { Additional controls (rural, } \\
\text { LMI, employment, } \\
\text { profitability, gender, and } \\
\text { veteran status) }\end{array}$ & $\mathrm{N}$ & $\mathrm{N}$ & $Y$ & $\mathrm{Y}$ \\
\hline Observations & 3,677 & 3,598 & 3,598 & 3,524 \\
\hline
\end{tabular}

\section{Discouraged firms}

Given the lower approval rates among minority-owned businesses, it is hardly surprising a larger share of these firms report they feel discouraged from applying for financing. In this context, feeling discouraged means a firm opted not to apply for financing, as it expected it would not be approved. Table 9 shows black-owned businesses have about two and a half times the rate of discouragement as white-owned firms. Asian and Hispanic owners have a discouraged rate about 50 percent greater than whites, but just under half that of black-owned firms. Surprisingly, this discouragement is persistent, especially between black and white small business owners, even among firms with more than \$1 million in revenues that are at least five years old, are low credit risks, and are profitable. The discouragement 
rate for profitable white-owned firms is just 7.5 percent, compared with 26.6 percent among blackowned firms. Similarly, for firms more than five years old, those owned by blacks are nearly four times as likely to be discouraged from applying as whites.

\section{Table 9: Share of Firms Discouraged from Applying for Financing}

\begin{tabular}{lrrrrr}
$\begin{array}{l}\text { Discouraged from } \\
\text { Applying }\end{array}$ & White & Black & Asian & Hispanic & All \\
\hline ALL & $14.2 \%$ & $38.0 \%$ & $20.2 \%$ & $20.5 \%$ & $16.6 \%$ \\
& & & & & \\
$<1 \mathrm{M}$ & $16.6 \%$ & $40.2 \%$ & $18.2 \%$ & $24.6 \%$ & $19.2 \%$ \\
$>1 \mathrm{M}$ in revenues & $7.0 \%$ & $18.1 \%$ & $9.8 \%$ & $9.9 \%$ & $8.0 \%$ \\
& & & & & \\
& $24.2 \%$ & $37.7 \%$ & $25.5 \%$ & $30.6 \%$ & $25.8 \%$ \\
< 5 years old & $10.4 \%$ & $38.3 \%$ & $16.4 \%$ & $14.3 \%$ & $12.6 \%$ \\
& & & & & \\
Low crears old & $10.6 \%$ & $15.1 \%$ & $12.4 \%$ & $9.9 \%$ & $11.2 \%$ \\
Medium credit risk & $35.3 \%$ & $51.7 \%$ & $37.1 \%$ & $38.4 \%$ & $39.1 \%$ \\
High credit risk & $77.8 \%$ & $84.8 \%$ & $79.6 \%$ & $75.9 \%$ & $78.5 \%$ \\
& & & & & \\
Not profitable & $22.7 \%$ & $43.4 \%$ & $35.9 \%$ & $30.4 \%$ & $25.9 \%$ \\
Profitable & $7.5 \%$ & $26.6 \%$ & $5.2 \%$ & $11.5 \%$ & $8.4 \%$
\end{tabular}

Source: Authors' calculations based on data from the 2016 Small Business Credit Survey

Table 10 displays the results from a logistic regression that predicts the likelihood a business feels discouraged from applying for a loan. While the coefficients on Asian- and Hispanic-owned firms are initially statistically significant, the differences between Asian- and white-owned firms disappear after controlling for firm age, industry, and revenue size, as seen in column two. The statistical significance of the difference between Hispanic- and white-owned firms disappear when additionally controlling for credit risk, as seen in column three.

We find black-owned firms are initially nearly 25 percent more likely to be discouraged from applying for financing when compared with white-owned firms when no other controls are included. The magnitude of the difference lessens as we add additional control variables, and we ultimately find that black-owned firms were 8.2 percent more likely to feel discouraged from applying for financing than white-owned firms. For most other groups of minority-owned businesses, it appears that various factors explain their discouragement, but for black-owned firms, a statistically significant difference persists. 


\section{Table 10: Discouraged from Applying for Loans}

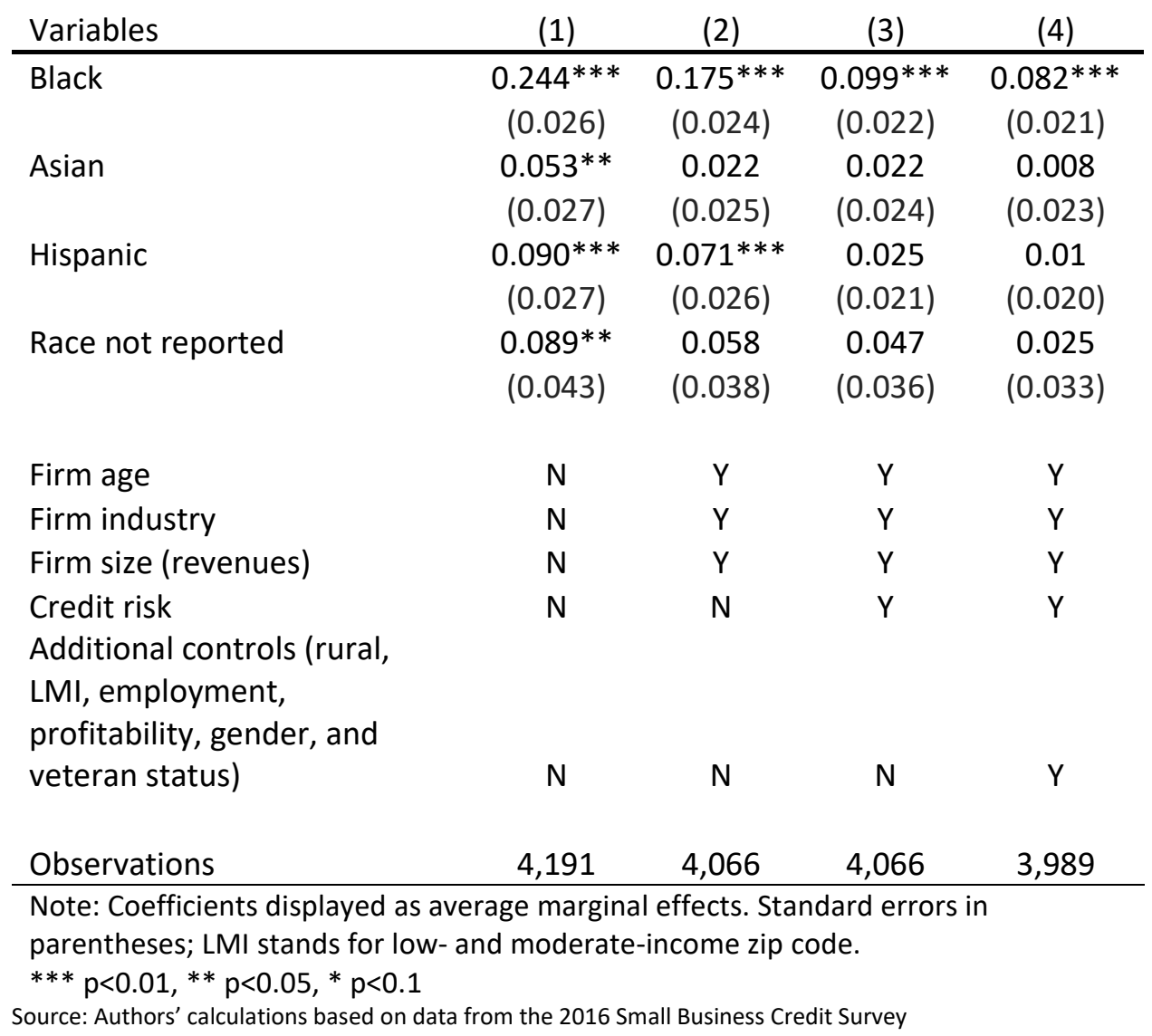

\section{Applications for online financing}

The online alternative lending industry has grown rapidly over the last decade, and small businesses, especially young firms, are increasingly tapping these sources for credit due to their lower hurdles in terms of loan requirements and their often-quicker response time in funding decisions. Indeed, the most recent 2017 Small Business Credit Survey employer firm report shows that 24 percent of small business applicants now turn to online lenders, up from 20 percent in 2015. However, this may come at a cost, as a relatively large share of applicants to online alternative products report facing challenges such as high interest rates and more onerous terms (Small Business Credit Survey, 2017). So, while this nascent industry may indeed be expanding access to credit, especially for minority borrowers, there are risks for businesses turning to these lenders (Jagtiani and Lemieux, 2017; Lipman and Weirch, 2015). Although overall satisfaction ratings for nonbank online lenders lag other types of lenders, they are on the rise: the net satisfaction percentage (the share of small business borrowers who are satisfied, minus the share who are unsatisfied) was 35 percent in 2017, up from 19 percent in 2015 (Small Business Credit Survey, 2017).

We find the share of black- and Hispanic-owned small businesses that apply to online financing is about twice as large, compared with white-owned firms (see table 11). Interestingly, we also note the 
difference between black- and white-owned firms is even larger for those with higher revenues (over $\$ 1$ million). Firms with high credit risk had strong but similar online application rates, with 45.3 percent of whites with high credit risk applying to online sources, compared with 47.9 percent of blacks. More interesting, however, is the fact that about one-quarter of low-risk black- and Hispanic-owned businesses applied for online financing, compared with just 10.5 percent of whites and 8.3 percent of Asians. The gaps in application rates between white owners and blacks or Hispanics were large and consistent across revenue classes, age classes, and profitability.

\section{Table 11: Share of Loan or Line of Credit Applicants Who Applied to an Online Lender}

\begin{tabular}{lccccc}
$\begin{array}{l}\text { Applied to Online } \\
\text { Financing }\end{array}$ & White & Black & Asian & Hispanics & All \\
\hline ALL & $17.1 \%$ & $32.8 \%$ & $23.0 \%$ & $35.6 \%$ & $20.2 \%$ \\
& & & & & \\
<1 M & $21.8 \%$ & $34.5 \%$ & $25.5 \%$ & $39.8 \%$ & $24.9 \%$ \\
$>1 \mathrm{M}$ in revenues & $10.2 \%$ & $29.7 \%$ & $18.3 \%$ & $17.8 \%$ & $12.0 \%$ \\
& & & & & \\
$<5$ years old & $21.1 \%$ & $35.4 \%$ & $26.1 \%$ & $36.3 \%$ & $24.2 \%$ \\
5+ years old & $14.8 \%$ & $30.5 \%$ & $19.7 \%$ & $35.0 \%$ & $17.6 \%$ \\
& & & & & \\
Low credit risk & $10.5 \%$ & $24.8 \%$ & $8.3 \%$ & $26.6 \%$ & $12.1 \%$ \\
Medium credit risk & $33.9 \%$ & $38.4 \%$ & $43.3 \%$ & $45.2 \%$ & $35.8 \%$ \\
High credit risk & $45.3 \%$ & $47.9 \%$ & $25.1 \%$ & $55.1 \%$ & $47.3 \%$ \\
& & & & & \\
Not profitable & $23.0 \%$ & $38.5 \%$ & $25.6 \%$ & $41.4 \%$ & $26.5 \%$ \\
Profitable & $12.2 \%$ & $27.3 \%$ & $19.3 \%$ & $25.0 \%$ & $14.2 \%$
\end{tabular}

Source: Authors' calculations based on data from the 2016 Small Business Credit Survey

Table 12 presents the results from the logistic regressions that predict the likelihood a business applies for a loan or line of credit at an online lender. Although the different racial and ethnic groups initially appear more likely to apply for a loan or line of credit than white-owned firms, the differences between Asian- and white-owned firms disappeared after introducing controls for firm revenue size, age, and industry. Still, we find that Hispanic-owned small businesses that apply for a loan or line of credit are 5 percent and black-owned businesses 3.8 percent more likely to apply to an online lender than are white-owned small businesses, even after controlling for firm-specific factors. 


\section{Table 12: Firms That Applied to an Online Lender for a Loan or Line of Credit}

\begin{tabular}{|c|c|c|c|c|}
\hline Variables & (1) & (2) & (3) & (4) \\
\hline \multirow[t]{2}{*}{ Black } & $0.165^{* * *}$ & $0.103 * * *$ & $0.049 * *$ & $0.038 *$ \\
\hline & $(0.025)$ & $(0.024)$ & $(0.021)$ & (0.021) \\
\hline \multirow[t]{2}{*}{ Asian } & $0.060 *$ & 0.044 & 0.039 & 0.023 \\
\hline & $(0.032)$ & $(0.031)$ & $(0.030)$ & (0.029) \\
\hline \multirow[t]{2}{*}{ Hispanic } & $0.125^{* * *}$ & $0.083 * * *$ & $0.059 * *$ & $0.050 *$ \\
\hline & $(0.032)$ & $(0.029)$ & $(0.028)$ & $(0.027)$ \\
\hline \multirow[t]{2}{*}{ Race not reported } & $0.137 * * *$ & $0.081^{*}$ & 0.067 & 0.055 \\
\hline & $(0.051)$ & $(0.046)$ & $(0.044)$ & $(0.043)$ \\
\hline Firm age & $\mathrm{N}$ & $\mathrm{Y}$ & $\mathrm{Y}$ & Y \\
\hline Firm industry & $\mathrm{N}$ & $\mathrm{Y}$ & $\mathrm{Y}$ & Y \\
\hline Firm size (revenues) & $\mathrm{N}$ & $\mathrm{Y}$ & $\mathrm{Y}$ & Y \\
\hline Credit risk & $\mathrm{N}$ & $\mathrm{N}$ & $\mathrm{Y}$ & $\mathrm{Y}$ \\
\hline $\begin{array}{l}\text { Additional controls (rural, } \\
\text { LMI, employment, } \\
\text { profitability, gender, and } \\
\text { veteran status) }\end{array}$ & $\mathrm{N}$ & $\mathrm{N}$ & $\mathrm{N}$ & Y \\
\hline Observations & 3,135 & 3,072 & 3,072 & 3,007 \\
\hline
\end{tabular}

\section{Approval for online financing}

For firms that applied for a loan or line of credit from an online lender, black-owned firms had the lowest approval rate (50.7 percent), while white-owned firms the highest approval rate (69.1 percent). Asian-owned firms had approval rates of 52.9 percent, closer to the rate for blacks, and Hispanic-owned businesses had a similar rate of approval as white-owned firms (68.4 percent). See table 13.

\section{Table 13: Share of Firms Approved for a Loan or Line of Credit from an Online Lender}

\section{Approved for Online Financing}

ALL
White

$$
69.1 \%
$$

Black

Asian

Hispanic

$50.7 \%$

$52.9 \%$

$68.4 \%$

$65.1 \%$

Source: Authors' calculations based on data from the 2016 Small Business Credit Survey 
The logistic regression employed here predicts the likelihood an applicant for a loan or online credit at a nonbank online lender receives approval for at least some of the financing requested. In the multivariate setting, we find no statistically significant differences after adding firm-specific controls. Although the direction of the coefficients on the race and ethnicity ownership variables is generally negative across all four models, the only statistically significant coefficient was for black-owned firms, and only before any firm-specific controls.

This could be a promising result, as it could indicate businesses are not receiving disparate treatment by online lenders, all things being equal, and/or such lenders are not collecting this information in their application process. However, we need to be somewhat cautious drawing such conclusions, as the results rely on a relatively small sample size and contain relatively large standard errors; see table $14 .^{20}$

\section{Table 14: Firms Approved by an Online Lender for a Loan or Line of Credit}

\begin{tabular}{lcccc} 
Variables & $(1)$ & $(2)$ & $(3)$ & $(4)$ \\
\hline Black & $-0.137^{* *}$ & -0.035 & -0.014 & -0.017 \\
& $(0.054)$ & $(0.051)$ & $(0.051)$ & $(0.053)$ \\
Asian & -0.122 & -0.118 & -0.115 & -0.121 \\
& $(0.091)$ & $(0.090)$ & $(0.090)$ & $(0.091)$ \\
Hispanic & -0.108 & -0.008 & 0.005 & 0.007 \\
& $(0.071)$ & $(0.064)$ & $(0.064)$ & $(0.065)$ \\
Race not reported & -0.105 & -0.089 & -0.069 & -0.046 \\
& $(0.109)$ & $(0.112)$ & $(0.112)$ & $(0.112)$ \\
& & & & \\
Firm age & $\mathrm{N}$ & $\mathrm{Y}$ & $\mathrm{Y}$ & $\mathrm{Y}$ \\
Firm industry & $\mathrm{N}$ & $\mathrm{Y}$ & $\mathrm{Y}$ & $\mathrm{Y}$ \\
Firm size (revenues) & $\mathrm{N}$ & $\mathrm{Y}$ & $\mathrm{Y}$ & $\mathrm{Y}$ \\
Credit risk & $\mathrm{N}$ & $\mathrm{N}$ & $\mathrm{Y}$ & $\mathrm{Y}$ \\
$\begin{array}{l}\text { Additional controls (rural, } \\
\text { LMI, employment, }\end{array}$ & & & & \\
profitability, gender, and & $\mathrm{N}$ & $\mathrm{N}$ & $\mathrm{N}$ & $\mathrm{Y}$ \\
veteran status) & & & & \\
$\begin{array}{l}\text { Observations } \\
\text { Pis }\end{array}$ & & & & 474 \\
\hline
\end{tabular}

Note: Coefficients displayed as average marginal effects. Standard errors in parentheses; LMI stands for low- and moderate-income zip code.

$* * * \mathrm{p}<0.01, * * \mathrm{p}<0.05, * \mathrm{p}<0.1$

Source: Authors' calculations based on data from the 2016 Small Business Credit Survey

${ }^{20}$ Sixty black-owned firms were included in the fourth model. 


\section{Lender satisfaction}

The Small Business Credit Survey asked respondents about their general satisfaction levels with the lending sources for their most recent two applications. As seen in table 15, minority-owned firms approved for at least some of the financing they requested or that had outstanding debt have much higher rates of dissatisfaction, compared with white-owned firms. This differential holds across size and age classes, risk categories, profitability, and other groups. Black-owned businesses have the highest rates of dissatisfaction, followed by Asian- and Hispanic-owned firms. Almost half of Asian-owned businesses with less than $\$ 1$ million in revenues were dissatisfied with their lenders, while nearly 40 percent of profitable Asian-owned businesses were dissatisfied.

\section{Table 15: Share of Applicants Approved for at Least Some Financing or with Outstanding Debt Who Were Dissatisfied with Their Lender}

\begin{tabular}{llllll}
$\begin{array}{l}\text { Dissatisfied with } \\
\text { lender }\end{array}$ & White & Black & Asian & Hispanic & All \\
\hline ALL & $19.5 \%$ & $41.4 \%$ & $39.3 \%$ & $31.5 \%$ & $22.6 \%$ \\
& & & & & \\
<1 M & $23.2 \%$ & $43.2 \%$ & $48.4 \%$ & $34.0 \%$ & $26.7 \%$ \\
$>1 \mathrm{M}$ in revenues & $14.5 \%$ & $29.3 \%$ & $26.2 \%$ & $27.9 \%$ & $16.2 \%$ \\
& & & & & \\
$<5$ years old & $23.4 \%$ & $43.8 \%$ & $36.7 \%$ & $39.1 \%$ & $27.1 \%$ \\
$5+$ years old & $17.9 \%$ & $39.6 \%$ & $41.3 \%$ & $27.1 \%$ & $20.5 \%$ \\
& & & & & \\
Low credit risk & $15.1 \%$ & $30.2 \%$ & $41.5 \%$ & $23.3 \%$ & $17.0 \%$ \\
Medium credit risk & $34.1 \%$ & $43.8 \%$ & $52.5 \%$ & $36.5 \%$ & $36.2 \%$ \\
High credit risk & $47.7 \%$ & $72.8 \%$ & $12.3 \%$ & $71.4 \%$ & $55.5 \%$ \\
& & & & & \\
Not profitable & $24.5 \%$ & $44.1 \%$ & $41.6 \%$ & $41.5 \%$ & $28.2 \%$ \\
Profitable & $14.7 \%$ & $32.1 \%$ & $37.9 \%$ & $23.9 \%$ & $16.8 \%$
\end{tabular}

Source: Authors' calculations based on data from the 2016 Small Business Credit Survey

Table 16 presents the results of the logistic regression that predicts the likelihood a firm is satisfied (or not) with their business lender. We find a persistent differential in dissatisfaction rates between minority- and white-owned businesses across the different model specifications and for all minority groups. Even after controlling for various firm-specific factors, the positive coefficients on black-, Asian-, and Hispanic-owned businesses were all statistically significant.

As shown in table 16, black-owned firms are 5.9 percent more likely to be dissatisfied with their lender, compared with white-owned businesses; Asian-owned firms are 16.5 percent more likely to 
report dissatisfaction; and Hispanic-owned firms are 9.6 percent more likely to do so, compared with white-owned firms. These results indicate all minority groups were more dissatisfied with their lenders than whites, and Asians and Hispanics were the most dissatisfied, when compared with whites.

\section{Table 16: Firms Approved for at Least Some Financing or with Outstanding Debt That Were Dissatisfied with Their Lender}

\begin{tabular}{lcccc} 
Variables & $(1)$ & $(2)$ & $(3)$ & $(4)$ \\
\hline Black & $0.206^{* * *}$ & $0.142^{* * *}$ & $0.082^{* * *}$ & $0.059^{* *}$ \\
& $(0.027)$ & $(0.025)$ & $(0.023)$ & $(0.023)$ \\
Asian & $0.199^{* * *}$ & $0.188^{* * *}$ & $0.179^{* * *}$ & $0.165^{* * *}$ \\
& $(0.035)$ & $(0.034)$ & $(0.033)$ & $(0.033)$ \\
Hispanic & $0.149 * * *$ & $0.129 * * *$ & $0.106^{* * *}$ & $0.096^{* * *}$ \\
& $(0.030)$ & $(0.029)$ & $(0.028)$ & $(0.028)$ \\
Race not reported & $0.122^{* *}$ & $0.093^{* *}$ & 0.065 & 0.056 \\
& $(0.049)$ & $(0.047)$ & $(0.044)$ & $(0.043)$ \\
& & & & \\
Firm age & $\mathrm{N}$ & $\mathrm{Y}$ & $\mathrm{Y}$ & $\mathrm{Y}$ \\
Firm industry & $\mathrm{N}$ & $\mathrm{Y}$ & $\mathrm{Y}$ & $\mathrm{Y}$ \\
Firm size (revenues) & $\mathrm{N}$ & $\mathrm{Y}$ & $\mathrm{Y}$ & $\mathrm{Y}$ \\
Credit risk & $\mathrm{N}$ & $\mathrm{N}$ & $\mathrm{Y}$ & $\mathrm{Y}$ \\
Additional controls (rural, & & & & \\
LMI, employment, & & & & \\
profitability, gender, and & & $\mathrm{N}$ & $\mathrm{N}$ & $\mathrm{Y}$ \\
veteran status) & $\mathrm{N}$ & & & \\
Observations & & 4,005 & 4,005 & 3,940 \\
\hline
\end{tabular}

Note: Coefficients displayed as average marginal effects. Standard errors in parentheses; LMI stands for low- and moderate-income zip code.

$* * * \mathrm{p}<0.01, * * \mathrm{p}<0.05, * \mathrm{p}<0.1$

Source: Authors' calculations based on data from the 2016 Small Business Credit Survey 


\section{Conclusion and Policy Implications}

The reported credit experiences of firms finds some evidence for gaps in credit approval by the race or ethnicity of the business owner, even when controlling for important firm characteristics such as self-reported personal and/or business credit scores, firm age, revenue size, and industry. Notably, black-owned firms are about 5 percent less likely to be approved, compared to similar white-owned firms. Additionally, we do find black-owned firms report being discouraged from applying for financing at significantly higher rates when compared with otherwise similar white-owned firms. Hispanic-owned firms, on the other hand, do not appear to be more or less likely to report being discouraged from applying for financing, compared with white-owned firms.

Hispanic- and black-owned firms are more likely than white-owned firms to apply for financing at nonbank online lenders. Both groups appear to have a similar likelihood of approval for financing from nonbank online sources as white-owned firms do. It is important to note, however, online lenders tend to have higher interest rates and lower average customer satisfaction levels. Prior research has suggested the terms of the loan are not always clear to the borrower (Jagtiani and Lemieux, 2017; Lippmann and Wiersch, 2015). Previous research by Schweitzer and Barkley (2017) found online borrowers have characteristics that make them similar to the businesses that were denied credit, which is consistent with online lenders issuing credit to businesses that do not qualify for more traditional financing. These factors could be related to white-owned firms not turning to nonbank online lenders as frequently. White-owned firms are more likely to obtain lower-cost credit products from traditional financial institutions, which appear to be more valuable at current margins than the quicker application process offered by online lenders. Since online lenders are a relatively recent entrant into the small business-financing sphere, future research should study the effect that leveraging these financing sources has on both credit access and business performance.

Of firms approved for at least some financing at any lender, or with outstanding debt, all groups of minority-owned firms are more likely to be dissatisfied with their lender than white-owned firms are. Asian-owned firms appear most likely to be dissatisfied with their lenders, after controlling for various factors.

We find that regardless of a number of firm-specific factors, some differences in credit market experiences remain, but our study does not seek to identify the cause of why credit outcomes and experiences differ by race or ethnicity of business ownership. Although the differences are challenging to interpret, research in this area suggests it could be due to a mix of factors, including differences in personal wealth levels, a firm's attitude or perception of credit markets or business opportunities, and either implicit or explicit racial bias on the part of lenders (Robb, 2013; Fairlie and Robb, 2010; Klein, 2017). Other factors could include a differential in access to networks or in financial literacy and business management capacity and knowledge levels. Potential approaches to address some of these differences could include technical assistance, such as training in business management practices, or financial literacy programming aimed specifically at minority-owned businesses. Programming that addresses language barriers for immigrant-owned businesses could also make an impact. Both the public sector and philanthropic actors have important roles to play in this space. 
Although this paper cannot fully assess conditions of minority-owned businesses or the underlying causes of those conditions, it does provide insight into the types of challenges many small business owners face. These include a sense of discouragement when considering whether to apply for credit as well as gaps in credit access, particularly for black-owned firms. As more data become available, whether from the Small Business Credit Survey, Annual Business Survey, or other efforts, it is important for researchers to investigate further whether and why such differences continue to appear. Improved knowledge of minority-owned firms' financing needs and gaps is fundamental to understanding and bolstering the entrepreneurial sector's health and growth, and this is increasingly important to the U.S. economy in general. 


\section{References}

Astebro, T.B., \& Bernhardt, I. (2005). "The Winner's Curse of Human Capital." Small Business Economics 24(1), 63-78.

Barkley, B., Robb, A., \& de Zeeuw, M.G. (2017). "2016 Small Business Credit Survey: Report on MinorityOwned Firms." Federal Reserve Bank of Cleveland, November.

Bates, T. (1997). Race, Self-Employment and Upward Mobility: An Elusive American Dream. Washington, DC: Woodrow Wilson Center Press and Baltimore: Johns Hopkins University Press.

Bates, T., \& Robb, A. (2013). "Greater Access to Capital Is Needed to Unleash the Local Economic Development Potential of Minority-Owned Businesses." Economic Development Quarterly 27, 250-259.

Bates, T., \& Robb, A. (2015a). "Has the Community Reinvestment Act Increased Loan Availability among Small Businesses Operating in Minority Neighborhoods?" Urban Studies 52, 1702-1721.

Bates, T., \& Robb, A. (2015b). "Impacts of Owner Race and Geographic Context on Access to Small Business Financing." Economic Development Quarterly 30, 159-170.

Berger, A.N., \& Udell, G.F. (1995). "Relationship Lending and Lines of Credit in Small Firm Finance." The Journal of Business 68(3), 351-381.

Black, S.E., \& Strahan, P.E. (2002). "Entrepreneurship and Bank Credit Availability.” The Journal of Finance 57(6), 2807-2833.

Blanchard, L., Zhao, B., \& Yinger, J. (2005). “Do Credit Market Barriers Exist for Minority and Women Entrepreneurs?” Syracuse University Working Paper.

Blanchflower, D.G., Levine, P.B., \& Zimmerman, D.J. (2003). “Discrimination in the Small-Business Credit Market." Review of Economics and Statistics 85(4), 930-943.

Cagetti, M. \& De Nardi, M. (2006). "Entrepreneurship, Frictions, and Wealth." Journal of Political Economy 114(5), 835-870.

Cavaluzzo, K., \& Wolken, J. (2005). "Small Business Loan Turndowns, Personal Wealth and Discrimination." Journal of Business 78, 2153-2178.

Chatterji, A.K., \& Seamans, R.C. (2012). Entrepreneurial Finance, Credit Cards, and Race." Journal of Financial Economics 106(1), 182-195.

Coleman, S. (2002). "The Borrowing Experience of Black and Hispanic-Owned Small Firms: Evidence from the 1998 Survey of Small Business Finances." The Academy of Entrepreneurship Journal 8: 1-20.

Coleman, S. (2002). "Borrowing Patterns for Small Firms: A Comparison by Race and Ethnicity." The Journal of Entrepreneurial Finance \& Business Ventures 7, 77-98. 
Evans, D.S., \& Jovanovic, B. (1989). "An Estimated Model of Entrepreneurial Choice under Liquidity Constraints." Journal of Political Economy 97(4), 808-827.

Fairlie, Robert (2006). "Entrepreneurship among Disadvantaged Groups: Women, Minorities and the Less Educated" in The Life Cycle of Entrepreneurial Ventures, International Handbook Series on Entrepreneurship 3, ed., Simon Parker. New York: Springer.

Fairlie, R., \& Robb, A. (2008). Race and Entrepreneurial Success: Black- Asian- and White-Owned Businesses in the United States. Cambridge, MA: MIT Press.

Fairlie, R., Robb, A. \& Robinson, D. (2016). "Black and White: Access to Capital among Minority-Owned Startups." Stanford Institute for Economic Policy Research discussion paper 17-03.

Fairlie, R.W., \& Robb, A.M. (2010). "Disparities in Capital Access between Minority and Non-MinorityOwned Businesses: The Troubling Reality of Capital Limitations Faced by MBEs." Washington, DC: U.S. Department of Commerce, Minority Business Development Agency.

Jagtiani, J., \& Lemieux, C. (2017). “Fintech Lending: Financial Inclusion, Risk Pricing, and Alternative Information. Federal Reserve Bank of Philadelphia Working Paper 17-17, July. Available at SSRN: https://ssrn.com/abstract=3005260.

Kerr, W.R., \& Nanda, R. (2009). "Democratizing Entry: Banking Deregulations, Financing Constraints, and Entrepreneurship." Journal of Financial Economics 94(1), 124-149.

Klein, J. (2017). Bridging the Divide: How Business Ownership Can Help Close the Racial Wealth Gap. Washington, DC: The Aspen Institute.

Lippmann, B.J., \& Wiersch, A.M. (2015). “Alternative Lending through the Eyes of 'Mom-and-Pop' SmallBusiness Owners: Findings from Online Focus Groups." Federal Reserve Bank of Cleveland, August. https://www.clevelandfed.org/newsroom-and-events/publications/special-reports/sr20150825-alternative-lending-through-the-eyes-of-mom-and-pop-small-business-owners.aspx.

Mitchell, K. \& Pearce, D.K. (2005). Availability of Financing to Small Firms Using the Survey of Small Business Finances. U.S. Small Business Administration, Office of Advocacy.

Robb, A.M. (2013). "Access to Capital among Young Firms, Minority-owned Firms, Women-owned Firms, and High-Tech Firms." Washington, DC: Small Business Administration.

Robb, A.M., \& Robinson, D.T. (2014). "The Capital Structure Decisions of New Firms." Review of Financial Studies, Society for Financial Studies 27(1), 153-179.

Schweitzer, M.E., \& Barkley, B. (2017). “Is 'Fintech' Good for Small Business Borrowers? Impacts on Firm Growth and Customer Satisfaction." Federal Reserve Bank of Cleveland Working Paper 17-01, February. https://www.clevelandfed.org/newsroom-and-events/publications/working-papers/2017working-papers/wp-1701-is-fintech-good-for-small-business-borrowers.aspx 
Battisto, J., de Zeeuw, M., Kramer Mills, C., Lieberman, S., Wiersch, A.M., (2017). "Small Business Credit Survey: Report on Employer Firms" Federal Reserve Banks of Atlanta, Boston, Chicago, Cleveland, Dallas, Kansas City, Minneapolis, New York, Philadelphia, Richmond, St. Louis, San Francisco, May.

Solon, G., Haider, S.J., \& Wooldridge, J.M. (2015). "What Are We Weighting For?" Journal of Human Resources 50(2), 301-316.

Williams, R. (2009). "Using Heterogenous Choice Models to Compare Logit and Probit Coefficients across Groups." Sociological Methods \& Research 37, 531-559. 


\section{Appendix}

Approved for Financing for All Applicants (Full Unweighted Results)

\begin{tabular}{|c|c|c|c|c|}
\hline Variables & (1) & $(2)$ & (3) & (4) \\
\hline \multirow[t]{2}{*}{ Black } & $-0.182 * * *$ & $-0.105^{* * *}$ & $-0.057 * * *$ & $-0.048 * *$ \\
\hline & $(0.025)$ & $(0.023)$ & $(0.022)$ & $(0.022)$ \\
\hline \multirow[t]{2}{*}{ Asian } & $-0.066 * *$ & -0.045 & -0.045 & -0.029 \\
\hline & $(0.031)$ & $(0.030)$ & $(0.030)$ & (0.029) \\
\hline \multirow[t]{2}{*}{ Hispanic } & $-0.102 * * *$ & $-0.067 * *$ & $-0.044 *$ & -0.038 \\
\hline & $(0.030)$ & $(0.028)$ & $(0.027)$ & $(0.026)$ \\
\hline \multirow[t]{2}{*}{ Race not reported } & $-0.088 *$ & -0.043 & -0.032 & -0.032 \\
\hline & $(0.048)$ & $(0.044)$ & $(0.043)$ & $(0.043)$ \\
\hline \multirow[t]{2}{*}{ Revenues: \$100K-\$1M } & & $0.061 * *$ & 0.042 & 0.016 \\
\hline & & $(0.029)$ & $(0.027)$ & $(0.025)$ \\
\hline \multirow[t]{2}{*}{ Revenues: \$1M-\$10M } & & $0.178 * * *$ & $0.137 * * *$ & $0.069 * *$ \\
\hline & & $(0.029)$ & $(0.028)$ & $(0.029)$ \\
\hline \multirow[t]{2}{*}{ Revenues: $<\$ 10 M$} & & $0.248 * * *$ & $0.201 * * *$ & $0.119 * * *$ \\
\hline & & $(0.031)$ & $(0.031)$ & (0.039) \\
\hline \multirow[t]{2}{*}{ Age: $3-5$ years } & & -0.035 & -0.028 & -0.026 \\
\hline & & $(0.025)$ & $(0.024)$ & $(0.024)$ \\
\hline \multirow[t]{2}{*}{ Age: $6-10$ years } & & -0.032 & -0.031 & $-0.039 *$ \\
\hline & & $(0.024)$ & $(0.023)$ & $(0.024)$ \\
\hline \multirow[t]{2}{*}{ Age: $11+$ years } & & -0.003 & -0.010 & -0.015 \\
\hline & & $(0.021)$ & $(0.021)$ & $(0.021)$ \\
\hline \multirow[t]{2}{*}{ Industry: Business support services } & & -0.026 & -0.028 & -0.034 \\
\hline & & $(0.037)$ & $(0.037)$ & $(0.037)$ \\
\hline \multirow[t]{2}{*}{ Industry: Accommodation and food services } & & -0.018 & -0.007 & -0.028 \\
\hline & & $(0.034)$ & $(0.034)$ & $(0.035)$ \\
\hline \multirow[t]{2}{*}{ Industry: Retail trade } & & $0.048^{*}$ & $0.052 *$ & $0.048^{*}$ \\
\hline & & $(0.028)$ & $(0.028)$ & $(0.028)$ \\
\hline \multirow[t]{2}{*}{ Industry: Personal services and repair services } & & 0.007 & 0.013 & 0.008 \\
\hline & & $(0.024)$ & $(0.024)$ & $(0.024)$ \\
\hline \multirow[t]{2}{*}{ Industry: Health care and child care } & & $0.095 * * *$ & $0.098 * * *$ & $0.085^{* * *}$ \\
\hline & & $(0.030)$ & $(0.030)$ & $(0.031)$ \\
\hline \multirow[t]{2}{*}{ Industry: Construction } & & 0.020 & 0.036 & 0.034 \\
\hline & & $(0.024)$ & $(0.024)$ & $(0.024)$ \\
\hline \multirow[t]{2}{*}{ Industry: Wholesale trade } & & $0.074^{*}$ & $0.080 * *$ & $0.087^{* *}$ \\
\hline & & $(0.038)$ & $(0.037)$ & $(0.035)$ \\
\hline \multirow[t]{2}{*}{ Industry: Real estate and rental services } & & 0.082 & $0.084 *$ & 0.071 \\
\hline & & $(0.050)$ & $(0.051)$ & $(0.052)$ \\
\hline \multirow[t]{2}{*}{ Industry: Finance and insurance } & & $0.143^{* * *}$ & $0.151 * * *$ & $0.144^{* * *}$ \\
\hline & & $(0.046)$ & $(0.045)$ & $(0.046)$ \\
\hline \multirow[t]{2}{*}{ Industry: Manufacturing } & & -0.014 & 0.000 & -0.012 \\
\hline & & $(0.027)$ & $(0.027)$ & $(0.027)$ \\
\hline
\end{tabular}


Industry: All other services or unsure

Credit risk: Medium

Credit risk: High

Credit risk: Did not respond

Rural

sing or storage

Veteran status: Veteran

Veteran status: Did not respond

Gender: Female

Gender: Did not respond

Profitable

Employee size: 5-9 employees

Employee size: 10-19 employees

Employee size: 20-49 employees

Employee size: 50-499 employees

Low- or moderate-income zip code

\begin{tabular}{|c|c|c|}
\hline $0.053^{* *}$ & $0.058 * * *$ & $0.051^{* *}$ \\
\hline$(0.022)$ & $(0.022)$ & $(0.022)$ \\
\hline 0.001 & 0.032 & 0.025 \\
\hline \multirow[t]{29}{*}{$(0.046)$} & $(0.043)$ & $(0.044)$ \\
\hline & $-0.146 * * *$ & $-0.137 * * *$ \\
\hline & (0.019) & (0.019) \\
\hline & $-0.225^{* * *}$ & $-0.189 * * *$ \\
\hline & $(0.038)$ & $(0.037)$ \\
\hline & $-0.035^{* *}$ & $-0.035 * *$ \\
\hline & (0.017) & $(0.017)$ \\
\hline & & $0.045^{* *}$ \\
\hline & & (0.018) \\
\hline & & $-0.042^{*}$ \\
\hline & & $(0.024)$ \\
\hline & & -0.005 \\
\hline & & $(0.016)$ \\
\hline & & -0.008 \\
\hline & & (0.015) \\
\hline & & -0.007 \\
\hline & & $(0.031)$ \\
\hline & & $0.080 * * *$ \\
\hline & & $(0.014)$ \\
\hline & & 0.018 \\
\hline & & (0.019) \\
\hline & & $0.049 * *$ \\
\hline & & $(0.021)$ \\
\hline & & $0.067 * * *$ \\
\hline & & $(0.024)$ \\
\hline & & $0.067^{* *}$ \\
\hline & & (0.031) \\
\hline & & -0.003 \\
\hline & & (0.013) \\
\hline
\end{tabular}

3,598

Note: Coefficients displayed as average marginal effects. Standard errors in parentheses; LMI stands for lowand moderate-income zip code.

$* * * p<0.01, * * p<0.05, * p<0.1$ 
Approved for Financing for All Applicants (Weighted)

\begin{tabular}{lcccc}
\hline Variables & $(1)$ & $(2)$ & $(3)$ & $(4)$ \\
\hline Black & $-0.190^{* * *}$ & $-0.123^{* * *}$ & $-0.078^{* *}$ & $-0.066^{*}$ \\
Asian & $(0.032)$ & $(0.030)$ & $(0.030)$ & $(0.035)$ \\
& $-0.070^{*}$ & $-0.055^{*}$ & -0.043 & -0.028 \\
Hispanic & $(0.035)$ & $(0.029)$ & $(0.031)$ & $(0.030)$ \\
& $-0.063^{*}$ & -0.031 & -0.012 & -0.009 \\
Race not reported & $(0.035)$ & $(0.037)$ & $(0.035)$ & $(0.036)$ \\
& $-0.163^{*}$ & -0.111 & -0.099 & -0.104 \\
& $(0.086)$ & $(0.075)$ & $(0.079)$ & $(0.080)$
\end{tabular}

Firm age

Firm industry

Firm size (revenues)

Credit risk

$\begin{array}{llll}N & Y & Y & Y \\ N & Y & Y & Y \\ N & Y & Y & Y \\ N & N & Y & Y\end{array}$

Additional controls (rural, LMI, employment, profitability, gender, and veteran status)

Observations $\mathrm{N}$ $\mathrm{N}$ $\mathrm{N}$ Y

Note: Coefficients displayed as average marginal effects. Standard errors in parentheses; LMI stands for low- and moderate-income zip code.

$* * * p<0.01, * * p<0.05, * p<0.1$

Discouraged from Applying (Full Unweighted Results)

\begin{tabular}{lcccc}
\hline Variables & $(1)$ & $(2)$ & $(3)$ & $(4)$ \\
\hline Black & $0.244^{* * *}$ & $0.175^{* * *}$ & $0.099^{* * *}$ & $0.082^{* * *}$ \\
Asian & $(0.026)$ & $(0.024)$ & $(0.022)$ & $(0.021)$ \\
& $0.053^{* *}$ & 0.022 & 0.022 & 0.008 \\
Hispanic & $(0.027)$ & $(0.025)$ & $(0.024)$ & $(0.023)$ \\
& $0.090^{* * *}$ & $0.071^{* * *}$ & 0.025 & 0.010 \\
Race not reported & $(0.027)$ & $(0.026)$ & $(0.021)$ & $(0.020)$ \\
& $0.089^{* *}$ & 0.058 & 0.047 & 0.025 \\
Revenues: \$100K-\$1M & $(0.043)$ & $(0.038)$ & $(0.036)$ & $(0.033)$ \\
& & -0.023 & -0.010 & 0.014 \\
Revenues: \$1M-\$10M & & $(0.019)$ & $(0.018)$ & $(0.015)$ \\
& & $-0.091 * * *$ & $-0.054 * * *$ & -0.009 \\
Revenues: $<\$ 10 M$ & & $(0.020)$ & $(0.019)$ & $(0.019)$ \\
& & $-0.157^{* * *}$ & $-0.119 * * *$ & $-0.052 *$ \\
Age: $3-5$ years & & $(0.021)$ & $(0.022)$ & $(0.028)$ \\
& & $-0.047^{*}$ & $-0.051 * *$ & -0.036 \\
& & $(0.025)$ & $(0.023)$ & $(0.022)$
\end{tabular}




\begin{tabular}{|c|c|c|c|}
\hline Age: $6-10$ years & $\begin{array}{c}-0.043^{*} \\
(0.024)\end{array}$ & $\begin{array}{c}-0.037^{*} \\
(0.022)\end{array}$ & $\begin{array}{c}-0.020 \\
(0.021)\end{array}$ \\
\hline Age: $11+$ years & $\begin{array}{c}-0.093 * * * \\
(0.022)\end{array}$ & $\begin{array}{c}-0.069 * * * \\
(0.020)\end{array}$ & $\begin{array}{c}-0.055^{* * *} \\
(0.019)\end{array}$ \\
\hline Industry: Business support services & $\begin{array}{c}-0.018 \\
(0.024)\end{array}$ & $\begin{array}{c}-0.038^{*} \\
(0.021)\end{array}$ & $\begin{array}{c}-0.049 * * \\
(0.021)\end{array}$ \\
\hline Industry: Accommodation and food services & $\begin{array}{c}0.014 \\
(0.023)\end{array}$ & $\begin{array}{l}-0.005 \\
(0.021)\end{array}$ & $\begin{array}{l}-0.003 \\
(0.022)\end{array}$ \\
\hline Industry: Retail trade & $\begin{array}{c}-0.002 \\
(0.020)\end{array}$ & $\begin{array}{l}-0.015 \\
(0.018)\end{array}$ & $\begin{array}{l}-0.019 \\
(0.018)\end{array}$ \\
\hline Industry: Personal services and repair services & $\begin{array}{c}0.017 \\
(0.017)\end{array}$ & $\begin{array}{c}0.000 \\
(0.016)\end{array}$ & $\begin{array}{c}-0.004 \\
(0.016)\end{array}$ \\
\hline Industry: Health care and child care & $\begin{array}{c}0.042 \\
(0.028)\end{array}$ & $\begin{array}{c}0.015 \\
(0.026)\end{array}$ & $\begin{array}{c}0.017 \\
(0.026)\end{array}$ \\
\hline Industry: Construction & $\begin{array}{l}0.040^{*} \\
(0.022)\end{array}$ & $\begin{array}{c}0.020 \\
(0.020)\end{array}$ & $\begin{array}{c}0.021 \\
(0.020)\end{array}$ \\
\hline Industry: Wholesale trade & $\begin{array}{c}0.094 * * \\
(0.040)\end{array}$ & $\begin{array}{c}0.084 * * \\
(0.037)\end{array}$ & $\begin{array}{c}0.070 * * \\
(0.035)\end{array}$ \\
\hline Industry: Real estate and rental services & $\begin{array}{c}0.003 \\
(0.039)\end{array}$ & $\begin{array}{l}-0.019 \\
(0.035)\end{array}$ & $\begin{array}{c}-0.018 \\
(0.036)\end{array}$ \\
\hline Industry: Finance and insurance & $\begin{array}{l}-0.046 \\
(0.033)\end{array}$ & $\begin{array}{l}-0.030 \\
(0.037)\end{array}$ & $\begin{array}{l}-0.006 \\
(0.043)\end{array}$ \\
\hline Industry: Manufacturing & $\begin{array}{c}0.048 * * \\
(0.024)\end{array}$ & $\begin{array}{c}0.036 \\
(0.022)\end{array}$ & $\begin{array}{c}0.032 \\
(0.021)\end{array}$ \\
\hline Industry: All other services or unsure & $\begin{array}{c}0.016 \\
(0.017)\end{array}$ & $\begin{array}{c}0.016 \\
(0.016)\end{array}$ & $\begin{array}{c}0.019 \\
(0.016)\end{array}$ \\
\hline Industry: Transportation, warehousing or storage & $\begin{array}{c}0.006 \\
(0.043)\end{array}$ & $\begin{array}{c}-0.004 \\
(0.041)\end{array}$ & $\begin{array}{c}0.005 \\
(0.042)\end{array}$ \\
\hline Credit risk: Medium & & $\begin{array}{c}0.227^{* * *} \\
(0.023)\end{array}$ & $\begin{array}{c}0.210 * * * \\
(0.022)\end{array}$ \\
\hline Credit risk: High & & $\begin{array}{c}0.567^{* * *} \\
(0.055)\end{array}$ & $\begin{array}{c}0.508^{* * *} \\
(0.056)\end{array}$ \\
\hline Credit risk: Did not respond & & $\begin{array}{c}0.001 \\
(0.010)\end{array}$ & $\begin{array}{c}0.001 \\
(0.010)\end{array}$ \\
\hline Rural & & & $\begin{array}{c}-0.035^{* * *} \\
(0.013)\end{array}$ \\
\hline Veteran status: Veteran & & & $\begin{array}{l}-0.007 \\
(0.019)\end{array}$ \\
\hline Veteran status: Did not respond & & & $\begin{array}{l}0.023^{*} \\
(0.012)\end{array}$ \\
\hline Gender: Female & & & $\begin{array}{c}0.009 \\
(0.011)\end{array}$ \\
\hline Gender: Did not respond & & & $\begin{array}{c}0.046 \\
(0.030)\end{array}$ \\
\hline Profitable & & & $-0.105 * * *$ \\
\hline
\end{tabular}


Employee size: 5-9 employees

Employee size: 10-19 employees

Employee size: 20-49 employees

Employee size: 50-499 employees

Low- or moderate-income zip code

Note: Coefficients displayed as average marginal effects. Standard errors in parentheses; LMI stands for lowand moderate-income zip code.

$* * * \mathrm{p}<0.01, * * \mathrm{p}<0.05, * \mathrm{p}<0.1$

Discouraged from Applying (Weighted)

\begin{tabular}{lcccc}
\hline Variables & $(1)$ & $(2)$ & $(3)$ & $(4)$ \\
\hline Black & $0.238^{* * *}$ & $0.169^{* * *}$ & $0.085^{* * *}$ & $0.058^{*}$ \\
& $(0.035)$ & $(0.031)$ & $(0.031)$ & $(0.031)$ \\
Asian & 0.060 & -0.000 & 0.006 & -0.003 \\
& $(0.054)$ & $(0.039)$ & $(0.036)$ & $(0.033)$ \\
Hispanic & 0.063 & 0.059 & 0.012 & 0.001 \\
& $(0.040)$ & $(0.037)$ & $(0.032)$ & $(0.032)$ \\
Race not reported & $0.095^{* *}$ & 0.062 & 0.060 & 0.044 \\
& $(0.047)$ & $(0.048)$ & $(0.054)$ & $(0.048)$ \\
Firm age & $\mathrm{N}$ & $\mathrm{Y}$ & $\mathrm{Y}$ & $\mathrm{Y}$ \\
Firm industry & $\mathrm{N}$ & $\mathrm{Y}$ & $\mathrm{Y}$ & $\mathrm{Y}$ \\
Firm size (revenues) & $\mathrm{N}$ & $\mathrm{Y}$ & $\mathrm{Y}$ & $\mathrm{Y}$ \\
Credit risk & $\mathrm{N}$ & $\mathrm{N}$ & $\mathrm{Y}$ & $\mathrm{Y}$ \\
Additional controls (rural, & & & & \\
LMI, employment, & & & & \\
profitability, gender, and & & $\mathrm{N}$ & $\mathrm{N}$ & $\mathrm{Y}$ \\
veteran status) & $\mathrm{N}$ & & & \\
Observations & & 4,066 & 4,066 & 3,989 \\
\hline
\end{tabular}

Note: Coefficients displayed as average marginal effects. Standard errors in parentheses; LMI stands for low- and moderate-income zip code.

*** $p<0.01,{ }^{* *} p<0.05, * p<0.1$ 
Firms That Applied to an Online Lender for a Loan or Line of Credit (Full Unweighted Results)

\begin{tabular}{|c|c|c|c|c|}
\hline Variables & $(1)$ & $(2)$ & (3) & $(4)$ \\
\hline \multirow[t]{2}{*}{ Black } & $0.165^{* * *}$ & $0.103 * * *$ & $0.049 * *$ & $0.038 *$ \\
\hline & $(0.025)$ & $(0.024)$ & $(0.021)$ & $(0.021)$ \\
\hline \multirow[t]{2}{*}{ Asian } & $0.060 *$ & 0.044 & 0.039 & 0.023 \\
\hline & $(0.032)$ & $(0.031)$ & $(0.030)$ & $(0.029)$ \\
\hline \multirow[t]{2}{*}{ Hispanic } & $0.125^{* * *}$ & $0.083 * * *$ & $0.059 * *$ & $0.050 *$ \\
\hline & $(0.032)$ & $(0.029)$ & $(0.028)$ & $(0.027)$ \\
\hline \multirow[t]{2}{*}{ Race not reported } & $0.137^{* * *}$ & $0.081^{*}$ & 0.067 & 0.055 \\
\hline & $(0.051)$ & $(0.046)$ & $(0.044)$ & $(0.043)$ \\
\hline \multirow[t]{2}{*}{ Revenues: $\$ 100 \mathrm{~K}-\$ 1 \mathrm{M}$} & & 0.021 & 0.037 & $0.039 *$ \\
\hline & & $(0.027)$ & $(0.024)$ & $(0.022)$ \\
\hline \multirow[t]{2}{*}{ Revenues: \$1M-\$10M } & & $-0.081 * * *$ & -0.039 & -0.008 \\
\hline & & $(0.027)$ & $(0.025)$ & $(0.026)$ \\
\hline \multirow[t]{2}{*}{ Revenues: $<\$ 10 M$} & & $-0.172 * * *$ & $-0.130 * * *$ & $-0.093 * * *$ \\
\hline & & $(0.027)$ & $(0.027)$ & $(0.032)$ \\
\hline \multirow[t]{2}{*}{ Age: $3-5$ years } & & 0.041 & 0.035 & 0.033 \\
\hline & & $(0.026)$ & $(0.025)$ & $(0.025)$ \\
\hline \multirow[t]{2}{*}{ Age: 6-10 years } & & 0.018 & 0.021 & 0.028 \\
\hline & & $(0.025)$ & $(0.024)$ & $(0.024)$ \\
\hline \multirow[t]{2}{*}{ Age: $11+$ years } & & -0.022 & -0.010 & -0.003 \\
\hline & & $(0.023)$ & $(0.022)$ & $(0.022)$ \\
\hline \multirow[t]{2}{*}{ Industry: Business support services } & & 0.038 & 0.036 & 0.035 \\
\hline & & $(0.035)$ & $(0.035)$ & $(0.035)$ \\
\hline \multirow[t]{2}{*}{ Industry: Accommodation and food services } & & 0.001 & -0.010 & 0.000 \\
\hline & & $(0.031)$ & $(0.030)$ & $(0.031)$ \\
\hline \multirow[t]{2}{*}{ Industry: Retail trade } & & 0.018 & 0.015 & 0.011 \\
\hline & & $(0.029)$ & $(0.029)$ & $(0.029)$ \\
\hline \multirow[t]{2}{*}{ Industry: Personal services and repair services } & & $0.054 * *$ & $0.046 *$ & $0.050 * *$ \\
\hline & & $(0.024)$ & $(0.024)$ & $(0.024)$ \\
\hline \multirow[t]{2}{*}{ Industry: Health care and child care } & & 0.012 & 0.010 & 0.019 \\
\hline & & $(0.033)$ & $(0.034)$ & $(0.035)$ \\
\hline \multirow[t]{2}{*}{ Industry: Construction } & & 0.019 & 0.000 & 0.000 \\
\hline & & $(0.023)$ & $(0.023)$ & $(0.023)$ \\
\hline \multirow[t]{2}{*}{ Industry: Wholesale trade } & & 0.055 & 0.041 & 0.029 \\
\hline & & $(0.046)$ & $(0.044)$ & $(0.042)$ \\
\hline \multirow[t]{2}{*}{ Industry: Real estate and rental services } & & $-0.103 * * *$ & $-0.109 * * *$ & $-0.104 * * *$ \\
\hline & & $(0.035)$ & $(0.036)$ & $(0.037)$ \\
\hline \multirow[t]{2}{*}{ Industry: Finance and insurance } & & 0.029 & 0.015 & 0.015 \\
\hline & & $(0.067)$ & $(0.064)$ & $(0.063)$ \\
\hline \multirow[t]{2}{*}{ Industry: Manufacturing } & & 0.015 & -0.003 & 0.003 \\
\hline & & $(0.026)$ & $(0.025)$ & $(0.025)$ \\
\hline \multirow[t]{2}{*}{ Industry: All other services or unsure } & & 0.012 & 0.005 & 0.004 \\
\hline & & $(0.022)$ & $(0.022)$ & $(0.022)$ \\
\hline
\end{tabular}


Industry: Transportation, warehousing or storage

Credit risk: Medium

Credit risk: High

Credit risk: Did not respond

Rural

Veteran status: Veteran

Veteran status: Did not respond

Gender: Female

Gender: Did not respond

Profitable

Employee size: 5-9 employees

Employee size: 10-19 employees

Employee size: 20-49 employees

Employee size: 50-499 employees

Low- or moderate-income zip code $\begin{array}{lll}0.084 * & 0.045 & 0.035\end{array}$

$\begin{array}{lll}(0.051) & (0.046) & (0.047)\end{array}$

$0.153^{* * *} \quad 0.145^{* * *}$

(0.020) (0.019)

$0.246^{* * *} \quad 0.234 * * *$

(0.039) (0.039)

$0.022 \quad 0.019$

(0.017) (0.017)

$-0.057 * * *$

(0.017)

$-0.001$

(0.023)

$-0.014$

(0.016)

$-0.004$

(0.015)

$-0.005$

(0.031)

$-0.074 * * *$

(0.014)

$-0.013$

$(0.018)$

$-0.012$

(0.021)

$-0.050 * *$

(0.023)

$-0.042$

(0.031)

$-0.010$

(0.013)

Observations

3,135

3,072

$3,072 \quad 3,007$

Note: Coefficients displayed as average marginal effects. Standard errors in parentheses; LMI stands for lowand moderate-income zip code.

$* * * p<0.01, * * p<0.05, * p<0.1$ 
Firms That Applied to an Online Lender for a Loan or Line of Credit (Weighted)

\begin{tabular}{lcccc}
\hline Variables & $(1)$ & $(2)$ & $(3)$ & $(4)$ \\
\hline Black & $0.157^{* * *}$ & $0.123^{* * *}$ & $0.061^{*}$ & 0.052 \\
& $(0.038)$ & $(0.041)$ & $(0.035)$ & $(0.037)$ \\
Asian & 0.059 & 0.046 & 0.023 & 0.006 \\
& $(0.067)$ & $(0.062)$ & $(0.047)$ & $(0.046)$ \\
Hispanic & $0.185^{* *}$ & $0.140^{* *}$ & $0.127^{* *}$ & $0.107^{* *}$ \\
& $(0.072)$ & $(0.060)$ & $(0.057)$ & $(0.052)$ \\
Race not reported & $0.163^{* *}$ & 0.102 & 0.077 & 0.071 \\
& $(0.062)$ & $(0.062)$ & $(0.060)$ & $(0.061)$
\end{tabular}

Firm age

Firm industry

Firm size (revenues)

Credit risk

$\begin{array}{llll}N & Y & Y & Y \\ N & Y & Y & Y \\ N & Y & Y & Y \\ N & N & Y & Y\end{array}$

Additional controls (rural, LMI, employment, profitability, gender, and veteran status)

Observations

$\begin{array}{llll}\mathrm{N} & \mathrm{N} & \mathrm{N} & \mathrm{Y}\end{array}$

Note: Coefficients displayed as average marginal effects. Standard errors in parentheses; LMI stands for low- and moderate-income zip code.

*** $\mathrm{p}<0.01,{ }^{* *} \mathrm{p}<0.05,{ }^{*} \mathrm{p}<0.1$

Firms Approved by an Online Lender for a Loan or Line of Credit (Full Unweighted Results)

\begin{tabular}{|c|c|c|c|c|}
\hline Variables & $(1)$ & $(2)$ & (3) & $(4)$ \\
\hline \multirow[t]{2}{*}{ Black } & $-0.137 * *$ & -0.035 & -0.014 & -0.017 \\
\hline & $(0.054)$ & $(0.051)$ & $(0.051)$ & $(0.053)$ \\
\hline \multirow[t]{2}{*}{ Asian } & -0.122 & -0.118 & -0.115 & -0.121 \\
\hline & (0.091) & $(0.090)$ & $(0.090)$ & $(0.091)$ \\
\hline \multirow[t]{2}{*}{ Hispanic } & -0.108 & -0.008 & 0.005 & 0.007 \\
\hline & $(0.071)$ & $(0.064)$ & $(0.064)$ & $(0.065)$ \\
\hline \multirow[t]{2}{*}{ Race not reported } & -0.105 & -0.089 & -0.069 & -0.046 \\
\hline & (0.109) & $(0.112)$ & $(0.112)$ & $(0.112)$ \\
\hline \multirow[t]{2}{*}{ Revenues: $\$ 100 \mathrm{~K}-\$ 1 \mathrm{M}$} & & $0.226 * * *$ & $0.221 * * *$ & $0.188 * *$ \\
\hline & & $(0.072)$ & $(0.071)$ & $(0.074)$ \\
\hline \multirow[t]{2}{*}{ Revenues: \$1M-\$10M } & & $0.405^{* * *}$ & $0.387 * * *$ & $0.335^{* * *}$ \\
\hline & & $(0.073)$ & $(0.074)$ & $(0.085)$ \\
\hline Revenues: $<\$ 10 M$ (Omitted) & & - & - & - \\
\hline \multirow[t]{2}{*}{ Age: $3-5$ years } & & -0.017 & -0.022 & -0.025 \\
\hline & & $(0.070)$ & $(0.069)$ & $(0.071)$ \\
\hline
\end{tabular}




\begin{tabular}{|c|c|c|c|}
\hline Age: $6-10$ years & $\begin{array}{c}0.047 \\
(0.070)\end{array}$ & $\begin{array}{c}0.042 \\
(0.069)\end{array}$ & $\begin{array}{c}0.029 \\
(0.071)\end{array}$ \\
\hline \multirow[t]{2}{*}{ Age: $11+$ years } & 0.017 & 0.004 & 0.013 \\
\hline & $(0.067)$ & $(0.066)$ & $(0.067)$ \\
\hline \multirow[t]{2}{*}{ Industry: Business support services } & -0.040 & -0.026 & -0.052 \\
\hline & $(0.102)$ & $(0.102)$ & $(0.104)$ \\
\hline \multirow[t]{2}{*}{ Industry: Accommodation and food services } & 0.083 & 0.097 & 0.075 \\
\hline & $(0.102)$ & $(0.100)$ & $(0.101)$ \\
\hline \multirow[t]{2}{*}{ Industry: Retail trade } & $0.236 * * *$ & $0.245^{* * *}$ & $0.206 * *$ \\
\hline & $(0.078)$ & $(0.077)$ & $(0.082)$ \\
\hline \multirow[t]{2}{*}{ Industry: Personal services and repair services } & $0.135 *$ & $0.130 *$ & 0.112 \\
\hline & $(0.069)$ & $(0.069)$ & $(0.070)$ \\
\hline \multirow[t]{2}{*}{ Industry: Health care and child care } & 0.110 & 0.100 & 0.118 \\
\hline & $(0.104)$ & $(0.104)$ & $(0.104)$ \\
\hline \multirow[t]{2}{*}{ Industry: Construction } & -0.088 & -0.072 & -0.068 \\
\hline & $(0.080)$ & $(0.080)$ & $(0.081)$ \\
\hline \multirow[t]{2}{*}{ Industry: Wholesale trade } & $0.243^{* *}$ & $0.251 * *$ & $0.222 * *$ \\
\hline & $(0.103)$ & $(0.102)$ & $(0.106)$ \\
\hline \multirow[t]{2}{*}{ Industry: Real estate and rental services } & -0.060 & -0.055 & -0.087 \\
\hline & $(0.312)$ & $(0.309)$ & $(0.308)$ \\
\hline \multirow[t]{2}{*}{ Industry: Finance and insurance } & 0.150 & 0.167 & 0.177 \\
\hline & $(0.156)$ & $(0.154)$ & $(0.143)$ \\
\hline \multirow[t]{2}{*}{ Industry: Manufacturing } & $0.154^{*}$ & $0.158 *$ & 0.118 \\
\hline & $(0.083)$ & $(0.082)$ & $(0.087)$ \\
\hline \multirow[t]{2}{*}{ Industry: All other services or unsure } & 0.104 & 0.118 & 0.093 \\
\hline & $(0.074)$ & $(0.074)$ & $(0.076)$ \\
\hline \multirow[t]{2}{*}{ Industry: Transportation, warehousing or storage } & 0.112 & 0.137 & 0.068 \\
\hline & $(0.116)$ & $(0.112)$ & $(0.127)$ \\
\hline \multirow[t]{2}{*}{ Credit risk: Medium } & & -0.054 & -0.037 \\
\hline & & $(0.046)$ & $(0.048)$ \\
\hline \multirow[t]{2}{*}{ Credit risk: High } & & $-0.160 * *$ & $-0.126^{*}$ \\
\hline & & $(0.065)$ & $(0.066)$ \\
\hline \multirow[t]{2}{*}{ Credit risk: Did not respond } & & -0.060 & -0.051 \\
\hline & & $(0.065)$ & $(0.067)$ \\
\hline \multirow[t]{2}{*}{ Rural } & & & 0.033 \\
\hline & & & $(0.070)$ \\
\hline \multirow[t]{2}{*}{ Veteran status: Veteran } & & & -0.011 \\
\hline & & & $(0.066)$ \\
\hline \multirow[t]{2}{*}{ Veteran status: Did not respond } & & & 0.051 \\
\hline & & & $(0.051)$ \\
\hline \multirow[t]{2}{*}{ Gender: Female } & & & -0.014 \\
\hline & & & $(0.045)$ \\
\hline \multirow[t]{2}{*}{ Gender: Did not respond } & & & -0.005 \\
\hline & & & $(0.090)$ \\
\hline Profitable & & & $0.097 * *$ \\
\hline
\end{tabular}


Employee size: 5-9 employees

Employee size: 10-19 employees

Employee size: 20-49 employees

Employee size: 50-499 employees

Low- or moderate-income zip code

Note: Coefficients displayed as average marginal effects. Standard errors in parentheses; LMI stands for lowand moderate-income zip code.

$* * * p<0.01, * * p<0.05, * p<0.1$

Firms Approved by an Online Lender for a Loan or Line of Credit (Weighted)

\begin{tabular}{lcccc}
\hline Variables & $(1)$ & $(2)$ & $(3)$ & $(4)$ \\
\hline Black & $-0.184^{* * *}$ & -0.085 & -0.070 & -0.090 \\
& $(0.067)$ & $(0.068)$ & $(0.072)$ & $(0.069)$ \\
Asian & -0.162 & -0.160 & -0.145 & -0.169 \\
& $(0.108)$ & $(0.109)$ & $(0.105)$ & $(0.105)$ \\
Hispanic & -0.007 & 0.087 & 0.093 & 0.091 \\
& $(0.088)$ & $(0.076)$ & $(0.073)$ & $(0.078)$ \\
Race not reported & -0.069 & -0.049 & -0.026 & 0.005 \\
& $(0.115)$ & $(0.145)$ & $(0.148)$ & $(0.145)$ \\
& & & & \\
Firm age & $\mathrm{N}$ & $\mathrm{Y}$ & $\mathrm{Y}$ & $\mathrm{Y}$ \\
Firm industry & $\mathrm{N}$ & $\mathrm{Y}$ & $\mathrm{Y}$ & $\mathrm{Y}$ \\
Firm size (revenues) & $\mathrm{N}$ & $\mathrm{Y}$ & $\mathrm{Y}$ & $\mathrm{Y}$ \\
Credit risk & $\mathrm{N}$ & $\mathrm{N}$ & $\mathrm{Y}$ & $\mathrm{Y}$ \\
Additional controls (rural, LMI, & & & & \\
employment, profitability, & & & & \\
gender, and veteran status) & $\mathrm{N}$ & $\mathrm{N}$ & $\mathrm{N}$ & $\mathrm{Y}$ \\
Observations & & & & \\
\hline
\end{tabular}

Note: Coefficients displayed as average marginal effects. Standard errors in parentheses; LMI stands for low- and moderate-income zip code.

*** $p<0.01,{ }^{* *} p<0.05, * p<0.1$ 
Firms Approved for at Least Some Financing or with Outstanding Debt That Were Dissatisfied with Their Lender (Full Unweighted Results)

\begin{tabular}{|c|c|c|c|c|}
\hline Variables & $(1)$ & $(2)$ & $(3)$ & $(4)$ \\
\hline Black & $\begin{array}{c}0.206 * * * \\
(0.027)\end{array}$ & $\begin{array}{c}0.142 * * * \\
(0.025)\end{array}$ & $\begin{array}{c}0.082 * * * \\
(0.023)\end{array}$ & $\begin{array}{c}0.059 * * \\
(0.023)\end{array}$ \\
\hline Asian & $\begin{array}{c}0.199 * * * \\
(0.035)\end{array}$ & $\begin{array}{c}0.188 * * * \\
(0.034)\end{array}$ & $\begin{array}{c}0.179 * * * \\
(0.033)\end{array}$ & $\begin{array}{c}0.165^{* * *} \\
(0.033)\end{array}$ \\
\hline Hispanic & $\begin{array}{c}0.149 * * * \\
(0.030)\end{array}$ & $\begin{array}{c}0.129 * * * \\
(0.029)\end{array}$ & $\begin{array}{c}0.106 * * * \\
(0.028)\end{array}$ & $\begin{array}{c}0.096 * * * \\
(0.028)\end{array}$ \\
\hline Race not reported & $\begin{array}{c}0.122^{* *} \\
(0.049)\end{array}$ & $\begin{array}{c}0.093^{* *} \\
(0.047)\end{array}$ & $\begin{array}{c}0.065 \\
(0.044)\end{array}$ & $\begin{array}{c}0.056 \\
(0.043)\end{array}$ \\
\hline Revenues: \$100K-\$1M & & $\begin{array}{c}-0.097 * * * \\
(0.031)\end{array}$ & $\begin{array}{c}-0.073 * * \\
(0.029)\end{array}$ & $\begin{array}{c}-0.065^{* *} \\
(0.029)\end{array}$ \\
\hline Revenues: \$1M-\$10M & & $\begin{array}{c}-0.163 * * * \\
(0.032)\end{array}$ & $\begin{array}{c}-0.112^{* * *} \\
(0.030)\end{array}$ & $\begin{array}{c}-0.087^{* * *} \\
(0.033)\end{array}$ \\
\hline Revenues: $<\$ 10 M$ & & $\begin{array}{c}-0.267 * * * \\
(0.033)\end{array}$ & $\begin{array}{c}-0.210 * * * \\
(0.033)\end{array}$ & $\begin{array}{c}-0.175^{* * *} \\
(0.039)\end{array}$ \\
\hline Age: $3-5$ years & & $\begin{array}{c}0.037 \\
(0.028)\end{array}$ & $\begin{array}{c}0.032 \\
(0.026)\end{array}$ & $\begin{array}{l}0.047^{*} \\
(0.026)\end{array}$ \\
\hline Age: 6-10 years & & $\begin{array}{c}0.016 \\
(0.026)\end{array}$ & $\begin{array}{c}0.018 \\
(0.025)\end{array}$ & $\begin{array}{c}0.037 \\
(0.024)\end{array}$ \\
\hline Age: $11+$ years & & $\begin{array}{l}-0.014 \\
(0.023)\end{array}$ & $\begin{array}{c}0.001 \\
(0.022)\end{array}$ & $\begin{array}{c}0.019 \\
(0.022)\end{array}$ \\
\hline Industry: Business support services & & $\begin{array}{c}0.021 \\
(0.034)\end{array}$ & $\begin{array}{c}0.016 \\
(0.034)\end{array}$ & $\begin{array}{c}0.011 \\
(0.034)\end{array}$ \\
\hline Industry: Accommodation and food services & & $\begin{array}{l}-0.040 \\
(0.028)\end{array}$ & $\begin{array}{l}-0.049 * \\
(0.028)\end{array}$ & $\begin{array}{l}-0.040 \\
(0.029)\end{array}$ \\
\hline Industry: Retail trade & & $\begin{array}{l}-0.008 \\
(0.026)\end{array}$ & $\begin{array}{l}-0.014 \\
(0.026)\end{array}$ & $\begin{array}{l}-0.008 \\
(0.026)\end{array}$ \\
\hline Industry: Personal services and repair services & & $\begin{array}{c}0.005 \\
(0.021)\end{array}$ & $\begin{array}{l}-0.004 \\
(0.021)\end{array}$ & $\begin{array}{l}-0.007 \\
(0.021)\end{array}$ \\
\hline Industry: Health care and child care & & $\begin{array}{c}0.030 \\
(0.035)\end{array}$ & $\begin{array}{c}0.018 \\
(0.034)\end{array}$ & $\begin{array}{c}0.023 \\
(0.034)\end{array}$ \\
\hline Industry: Construction & & $\begin{array}{c}0.030 \\
(0.023)\end{array}$ & $\begin{array}{c}0.007 \\
(0.022)\end{array}$ & $\begin{array}{c}0.010 \\
(0.022)\end{array}$ \\
\hline Industry: Wholesale trade & & $\begin{array}{l}-0.010 \\
(0.037)\end{array}$ & $\begin{array}{l}-0.021 \\
(0.036)\end{array}$ & $\begin{array}{l}-0.030 \\
(0.035)\end{array}$ \\
\hline Industry: Real estate and rental services & & $\begin{array}{l}-0.020 \\
(0.053)\end{array}$ & $\begin{array}{l}-0.025 \\
(0.053)\end{array}$ & $\begin{array}{l}-0.030 \\
(0.053)\end{array}$ \\
\hline Industry: Finance and insurance & & $\begin{array}{l}-0.076 \\
(0.048)\end{array}$ & $\begin{array}{l}-0.086 * \\
(0.047)\end{array}$ & $\begin{array}{c}-0.073 \\
(0.050)\end{array}$ \\
\hline Industry: Manufacturing & & $\begin{array}{l}0.045^{*} \\
(0.024)\end{array}$ & $\begin{array}{c}0.029 \\
(0.024)\end{array}$ & $\begin{array}{c}0.031 \\
(0.024)\end{array}$ \\
\hline Industry: All other services or unsure & & 0.015 & 0.006 & 0.003 \\
\hline
\end{tabular}


Industry: Transportation, warehousing or storage

Credit risk: Medium

Credit risk: High

Credit risk: Did not respond

Rural

Veteran status: Veteran

Veteran status: Did not respond

Gender: Female

Gender: Did not respond

Profitable

Employee size: 5-9 employees

Employee size: 10-19 employees

Employee size: 20-49 employees

Employee size: 50-499 employees

Low- or moderate-income zip code

\begin{tabular}{|c|c|c|}
\hline$(0.022)$ & $(0.022)$ & $(0.021)$ \\
\hline 0.051 & 0.007 & 0.000 \\
\hline \multirow[t]{29}{*}{ (0.049) } & $(0.044)$ & $(0.045)$ \\
\hline & $0.170 * * *$ & $0.161^{* * *}$ \\
\hline & $(0.020)$ & $(0.020)$ \\
\hline & $0.313^{* * *}$ & $0.296 * * *$ \\
\hline & $(0.044)$ & $(0.044)$ \\
\hline & -0.009 & -0.009 \\
\hline & $(0.015)$ & $(0.015)$ \\
\hline & & $-0.056 * * *$ \\
\hline & & $(0.016)$ \\
\hline & & $0.073 * * *$ \\
\hline & & $(0.024)$ \\
\hline & & $0.029 *$ \\
\hline & & $(0.016)$ \\
\hline & & -0.003 \\
\hline & & (0.014) \\
\hline & & 0.036 \\
\hline & & (0.031) \\
\hline & & $-0.068 * * *$ \\
\hline & & $(0.013)$ \\
\hline & & 0.020 \\
\hline & & (0.017) \\
\hline & & 0.012 \\
\hline & & $(0.020)$ \\
\hline & & -0.015 \\
\hline & & $(0.022)$ \\
\hline & & 0.004 \\
\hline & & $(0.030)$ \\
\hline & & -0.011 \\
\hline & & $(0.012)$ \\
\hline
\end{tabular}

$\begin{array}{lll}(0.022) & (0.022) \quad(0.021)\end{array}$

$\begin{array}{lll}0.051 & 0.007 & 0.000\end{array}$

$0.170 * * * \quad 0.161^{* * *}$

$(0.020) \quad(0.020)$

$\begin{array}{ll}0.313^{* * *} & 0.296 * * \\ (0.044) & (0.044)\end{array}$

$-0.009 \quad-0.009$

$-0.056 * * *$

(0.016)

(0.024)

$0.029 *$

$(0.016)$

(0.014)

0.036

$-0.068 * * *$

$(0.013)$

0.020

$(0.017)$

0.012

$(0.020)$

$-0.015$

$(0.022)$

0.004

$(0.030)$

(0.012)

Observations

4,073

4,005

4,005

3,940

Note: Coefficients displayed as average marginal effects. Standard errors in parentheses; LMI stands for lowand moderate-income zip code.

*** $p<0.01,{ }^{* *} p<0.05, * p<0.1$ 
Firms Approved for at Least Some Financing or with Outstanding Debt That Were Dissatisfied with their Lender (Weighted)

\begin{tabular}{lcccc}
\hline Variables & $(1)$ & $(2)$ & $(3)$ & $(4)$ \\
\hline Black & $0.219^{* * *}$ & $0.138^{* * *}$ & $0.083^{* *}$ & $0.064^{*}$ \\
Asian & $(0.036)$ & $(0.038)$ & $(0.034)$ & $(0.034)$ \\
& $0.198^{* * *}$ & $0.209^{* * *}$ & $0.189^{* * *}$ & $0.180^{* * *}$ \\
Hispanic & $(0.051)$ & $(0.061)$ & $(0.062)$ & $(0.063)$ \\
& $0.120^{* * *}$ & $0.102^{* * *}$ & $0.088^{* * *}$ & $0.080^{* *}$ \\
Race not reported & $(0.028)$ & $(0.028)$ & $(0.030)$ & $(0.031)$ \\
& $0.132^{* *}$ & $0.125^{* *}$ & 0.091 & 0.076 \\
Firm age & $(0.065)$ & $(0.061)$ & $(0.057)$ & $(0.053)$ \\
Firm industry & $0.120^{* * *}$ & $0.102^{* * *}$ & $0.088^{* * *}$ & $0.080^{* *}$ \\
Firm size (revenues) & $\mathrm{N}$ & $\mathrm{Y}$ & $\mathrm{Y}$ & $\mathrm{Y}$ \\
Credit risk & $\mathrm{N}$ & $\mathrm{Y}$ & $\mathrm{Y}$ & $\mathrm{Y}$ \\
Additional controls (rural, LMI, & $\mathrm{N}$ & $\mathrm{Y}$ & $\mathrm{Y}$ & $\mathrm{Y}$ \\
employment, profitability, gender, & $\mathrm{N}$ & $\mathrm{N}$ & $\mathrm{Y}$ & $\mathrm{Y}$ \\
and veteran status) & & & & \\
Observations & $\mathrm{N}$ & $\mathrm{N}$ & $\mathrm{N}$ & $\mathrm{Y}$ \\
\hline
\end{tabular}

Note: Coefficients displayed as average marginal effects. Standard errors in parentheses; LMI stands for low- and moderate-income zip code.

*** $\mathrm{p}<0.01, * * \mathrm{p}<0.05, * \mathrm{p}<0.1$ 